\title{
Leveraging the Fragment Length of Circulating Tumour DNA to Improve Molecular Profiling of Solid Tumour Malignancies with Next-Generation Sequencing: A Pathway to Advanced Non-invasive Diagnostics in Precision Oncology?
}

\author{
Hunter R. Underhill ${ }^{1,2,3}$ (D) \\ Accepted: 29 April 2021 / Published online: 20 May 2021 \\ (c) The Author(s) 2021
}

\begin{abstract} in oncology.

\section{Why is the Fragment Length of Circulating Tumour DNA (ctDNA) Important?}

Circulating cell-free DNA (ccfDNA) has emerged as a promising diagnostic tool in oncology. Identification of tumour-derived ccfDNA (i.e. circulating tumour DNA [ctDNA]) provides non-invasive access to a malignancy's molecular landscape to diagnose, inform therapeutic strategies, and monitor treatment efficacy. Current applications of ccfDNA to detect somatic mutations, however, have been largely constrained to tumour-informed searches and identification of common mutations because of the interaction between ctDNA signal and next-generation sequencing (NGS) noise. Specifically, the low allele frequency of ctDNA associated with non-metastatic and early-stage lesions may be indistinguishable from artifacts that accrue during sample preparation and NGS. Thus, using ccfDNA to achieve non-invasive and personalized molecular profiling to optimize individual patient care is a highly sought goal that remains limited in clinical practice. There is growing evidence, however, that further advances in the field of ccfDNA diagnostics may be achieved by improving detection of somatic mutations through leveraging the inherently shorter fragment lengths of ctDNA compared to non-neoplastic ccfDNA. Here, the origins and rationale for seeking to improve the mutation-based detection of ctDNA by using ccfDNA size profiling are reviewed. Subsequently, in vitro and in silico methods to enrich for a target ccfDNA fragment length are detailed to identify current practices and provide perspective into the potential of using ccfDNA size profiling to impact clinical applications

In 1948, the presence of DNA in plasma without a protective membrane, which has been subsequently termed circulating cell-free DNA (ccfDNA) (Fig. 1a), was described by Mandel and Métais [1]. In 1977, the first report of a difference in the ccfDNA concentration $(\mathrm{ng} / \mathrm{mL}$ plasma) between cancer patients and healthy individuals hinted at the possibility of harnessing ccfDNA as a diagnostic tool

Hunter R. Underhill

Hunter.Underhill@hsc.utah.edu

1 Division of Medical Genetics, Department of Pediatrics, University of Utah, 295 Chipeta Way, Salt Lake City, UT 84108, USA

2 Department of Radiology, University of Utah, Salt Lake City, UT, USA

3 Huntsman Cancer Institute, University of Utah, Salt Lake City, UT, USA in clinical oncology [2]. Unfortunately, applications based on ccfDNA concentration alone proved limited because of significant overlap between healthy individuals and patients with cancer, particularly patients with early-stage and nonmetastatic disease [2-5]. In addition, factors such as age [6], weight [7], inflammation [8], infection [9], and exercise [10], among other clinical factors, have been shown to affect ccfDNA abundancy, likely undermining the use of ccfDNA concentration to discern and monitor malignancy [11]. Thus, the 1994 discovery of a KRAS p.G12D point mutation in ccfDNA derived from pancreatic cancer was a landmark occasion because the detection of tumour-derived ccfDNA (circulating tumour DNA [ctDNA]) provided incontrovertible molecular proof for the viability of the non-invasive detection of cancer [12].

Haematopoietic cells account for $>90 \%$ of the ccfDNA in healthy individuals [13-16]. The remaining portion of ccfDNA is principally derived from endothelial cells and hepatocytes $[13,14,16]$. In the presence of solid tumours, the proportion of ccfDNA composed of ctDNA is generally 


\section{Key Findings/Implications}

Application of next-generation sequencing for the detection of somatic mutations in circulating cell-free DNA derived from solid tumour malignancies seeks to revolutionize precision medicine by using a simple blood draw to detect cancers, monitor response to therapies, and personalize treatment strategies.

Advancing cell-free DNA diagnostics to early-stage and non-metastatic cancers has been limited by challenges associated with distinguishing the true signal of lowfrequency tumour-derived cell-free DNA from noise generated during next-generation sequencing.

Differences in the fragment length between tumourderived cell-free DNA (circulating tumour DNA [ctDNA]) and cell-free DNA originating from healthy cells is a biologic phenomenon that can be leveraged to improve detection of ctDNA.

Both laboratory-based (in vitro) and computer-based (in silico) methods are being developed to use the fragment length profile of ctDNA to improve cell-free DNA diagnostics in cancer.

Further investigations into using size-based analyses in difficult to detect cancers are necessary to expand the role of cell-free DNA in non-invasive applications of precision oncology.

correlated to disease severity [3]. In advanced and metastatic disease, the somatic mutations present in ctDNA may overwhelm the wild-type alleles derived from haematopoietic cell DNA and appear with strikingly high allele frequencies (> 20\% [17]). In turn, the allele frequency of ctDNA associated with early-stage or non-metastatic disease may be quite low $(<1 \%)$. Because a widely sought goal of ccfDNA diagnostics is detection of ctDNA before advanced disease occurs to potentially maximize therapeutic options, the field has been driven towards development of sensitive methods to identify ctDNA among the abundant ccfDNA from normal healthy cells - the proverbial "needle in a haystack". From 1994 to 2012, research efforts were largely led by polymerase chain reaction (PCR)-based methods conducting narrow tumour-informed searches or analysing common tumourigenic loci (e.g. EGFR p.T790M) for evidence of ctDNA. During this period, ctDNA was detected from malignancies associated with a multitude of organs, such as the colon [3], breast [18], prostate [19], lung [20], skin [21], and pancreas [22] among others. In some instances, detection of ctDNA correlated with poor survival [23]. Other studies found that serial quantitative monitoring of ctDNA informed responses to therapy [24]. Overall, however, the successful detection of ctDNA based on mutation detection tended towards advanced disease where the ctDNA fraction was generally observed at $>1 \%$.

In 2012, the first uses of next-generation sequencing (NGS) to detect ctDNA were detailed [25, 26]. Integration of NGS into ccfDNA diagnostics promised the broader characterization of ctDNA because capture-enrichment panels used during NGS can be customized to target a wide range of molecular foci depending on the desired applications. Thus, detection of ctDNA could move beyond a narrow search to a broad surveillance of a multitude of genes enabling a more extensive genotyping through perfusion sampling rather than focal tissue analysis. Theoretically, NGS should enable substantial advances in precision oncology via (1) detection of both common and patient-specific mutations, (2) monitoring of molecular evolution, and (3) detection of ctDNA derived from metastatic lesions with a potentially separate molecular profile. Each of these mutation-based features is key in the advancement of personalized medicine through the enabling of treatment optimization for each patient's genotypically unique primary and possibly distal lesions. Although NGS is on par with PCR-based methods in ability to detect ctDNA from a wide array of human cancers [27], further attainment of NGS's potential has been constrained by assay noise generated during NGS because a portion of artifacts can occur randomly with an allele frequency similar to low-frequency ctDNA [28]. An overview of publications from 2016 to 2020 highlights several key effects of NGSassociated noise on the mutation-based detection of ctDNA (Fig. 2, [29-142]). First, the sensitivity of a mutation-based ctDNA detection strategy to identify cancer reveals a high degree of variability across all disease severities (Figs. 2, 3a, b). Although detection of advanced and metastatic disease of some cancers has improved, others remain challenging likely indicating a low ctDNA burden associated with some cancers regardless of clinical stage. As such, development of more sensitive techniques to discern ctDNA from noise may not only extend ctDNA applications to a broader range of cancer types and stages, but also improve characterization of genetic heterogeneity in advanced cancers. Second, a large portion of studies use a tumour-informed search to guide mutation-based ctDNA detection to distinguish true positives from false positive (Fig. 2). Thus, the ctDNA mutational landscape is constrained to somatic mutations present in a focal tissue sample that may not adequately represent genetic heterogeneity of the primary tumour and/or mutations unique to metastatic lesions. In addition, dependence on tumour DNA to detect ctDNA largely voids the concept of the non-invasive liquid biopsy, particularly applications pertaining to diagnosis and monitoring of molecular 
a

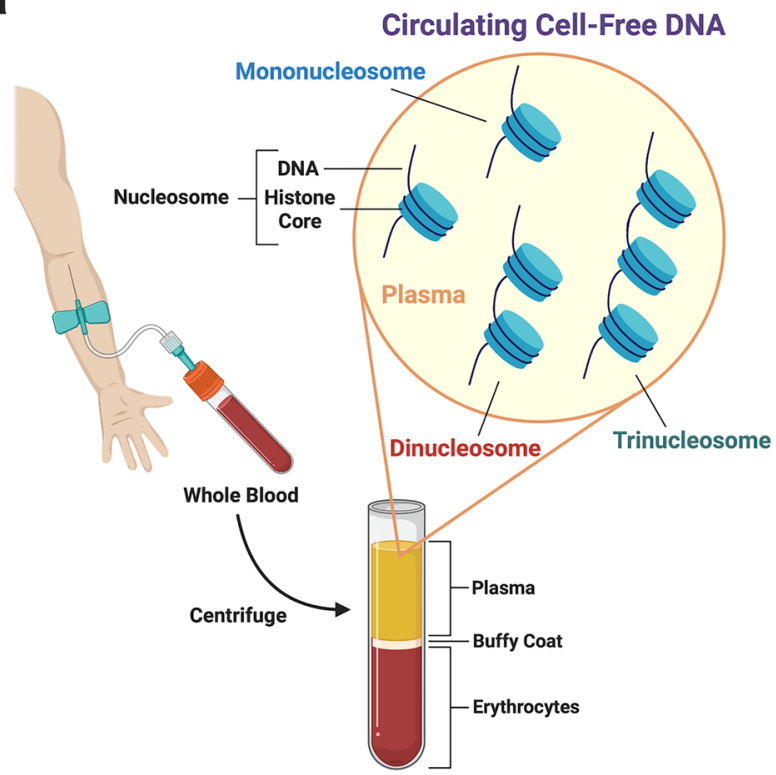

Fig. 1 Acquisition and characteristics of circulating cell-free DNA (ccfDNA). Whole blood acquired through venipuncture is centrifuged to separate plasma from buffy coat and erythrocytes (a). ccfDNA derived from apoptosis is present in plasma as various multiples of nucleosomes-DNA wrapped around a histone core with a linker fragment of DNA ( 10 bp) joining adjacent nucleosomes (a). The relative quantity and fragment length distribution of ccfDNA is

evolution. Finally, inclusion of healthy control ccfDNA is uncommon in studies searching for ctDNA with or without a priori knowledge of somatic mutations (Fig. 2). Because a principal component of NGS-associated error is stochastic [28, 143], investigations using a mutation-based detection of ctDNA without validating specificity pertinent to the experimental design may be challenging to interpret due to the confounding effects random noise may have on identification of low-frequency ctDNA, especially when tumour DNA is not used as a guide. Collectively, the data presented in Fig. 2 and 3 show positive trends in the overall progress achieved in the past 5 years, but also provide compelling evidence that the true potential of NGS-based ccfDNA diagnostics in precision oncology remains unrealized. As such, laboratory methods, technical innovations, or both to improve the signal-to-noise ratio during NGS are needed to translate mutation-based ctDNA detection into impactful clinical applications.

One route to improving detection of low-frequency variants is using a larger DNA input so that the signal exceeds the level of noise. Unfortunately, the amount of ccfDNA in plasma is finite. In healthy individuals, the concentration of ccfDNA ranges between 5 and $15 \mathrm{ng} / \mathrm{mL}$ plasma b
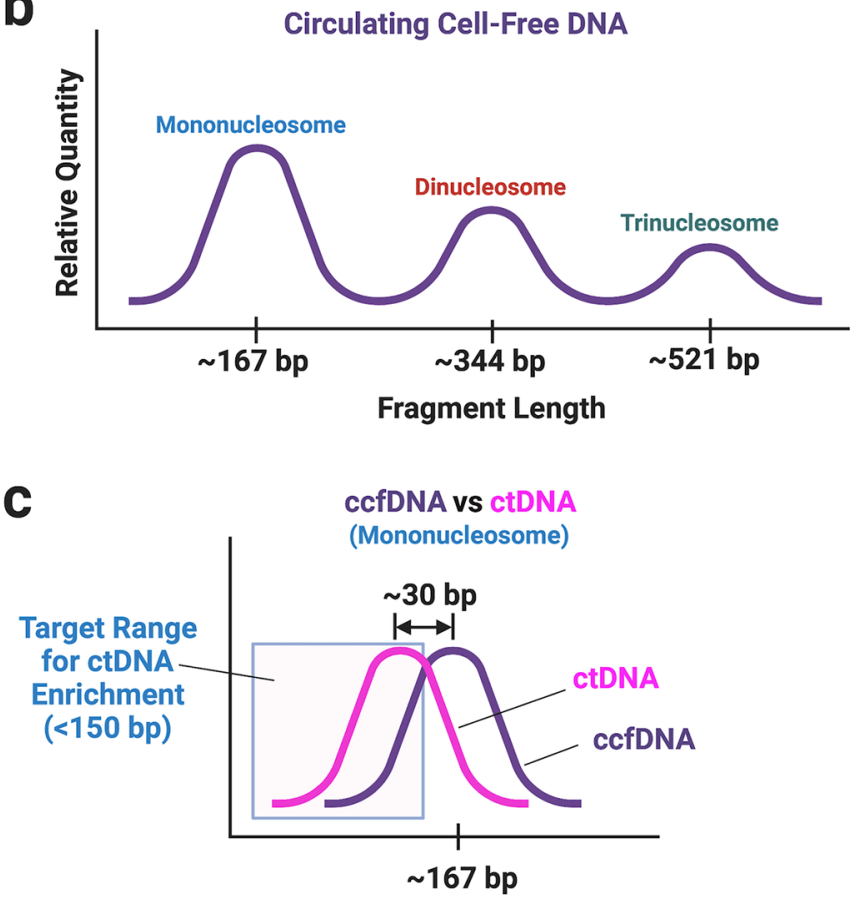

shown in (b), where the most abundant fragment length corresponds to the length of the mononucleosome. The fragment lengths of circulating tumour DNA (ctDNA) tend to be shorter than ccfDNA (c); however, there is substantial overlap. Enrichment of ctDNA has generally focused on isolation of fragment lengths $<150 \mathrm{bp}$ to improve the ratio between ctDNA and ccfDNA

and the quantity of ccfDNA in patients with early-stage or non-metastatic disease is similar or only marginally higher. As a reference point, a single human cell (diploid) contains $7 \mathrm{pg}$ of DNA. In $1 \mathrm{ng}$ of human DNA, each genomic position associated with the non-sex chromosomes is represented 286 times (i.e. genomic equivalents). Thus, a 30-ng ccfDNA library input provides $\sim 8580$ unique copies of DNA at each base position assuming a lossless library preparation and absence of gene amplifications and deletions. Using NGS, a ctDNA variant with an allele frequency of $0.05 \%$ may be indistinguishable from noise because fewer than five unique copies of the mutation under ideal conditions are present in the sequencing data. Because of losses that occur during sample handling for NGS in combination with the low quantity of cell-free DNA in plasma, achieving the necessary boost in signal at such low allele frequencies to overcome NGS-associated noise requires large volumes of blood (i.e. $>100 \mathrm{~mL}$ [121]). However, a distinctive characteristic of ctDNA may help overcome these signal-to-noise obstacles. There is growing evidence that the predominance of ctDNA occurs with a fragment length shorter than ccfDNA from healthy cells. Given the challenges associated with detecting ctDNA derived from early-stage and non-metastatic 

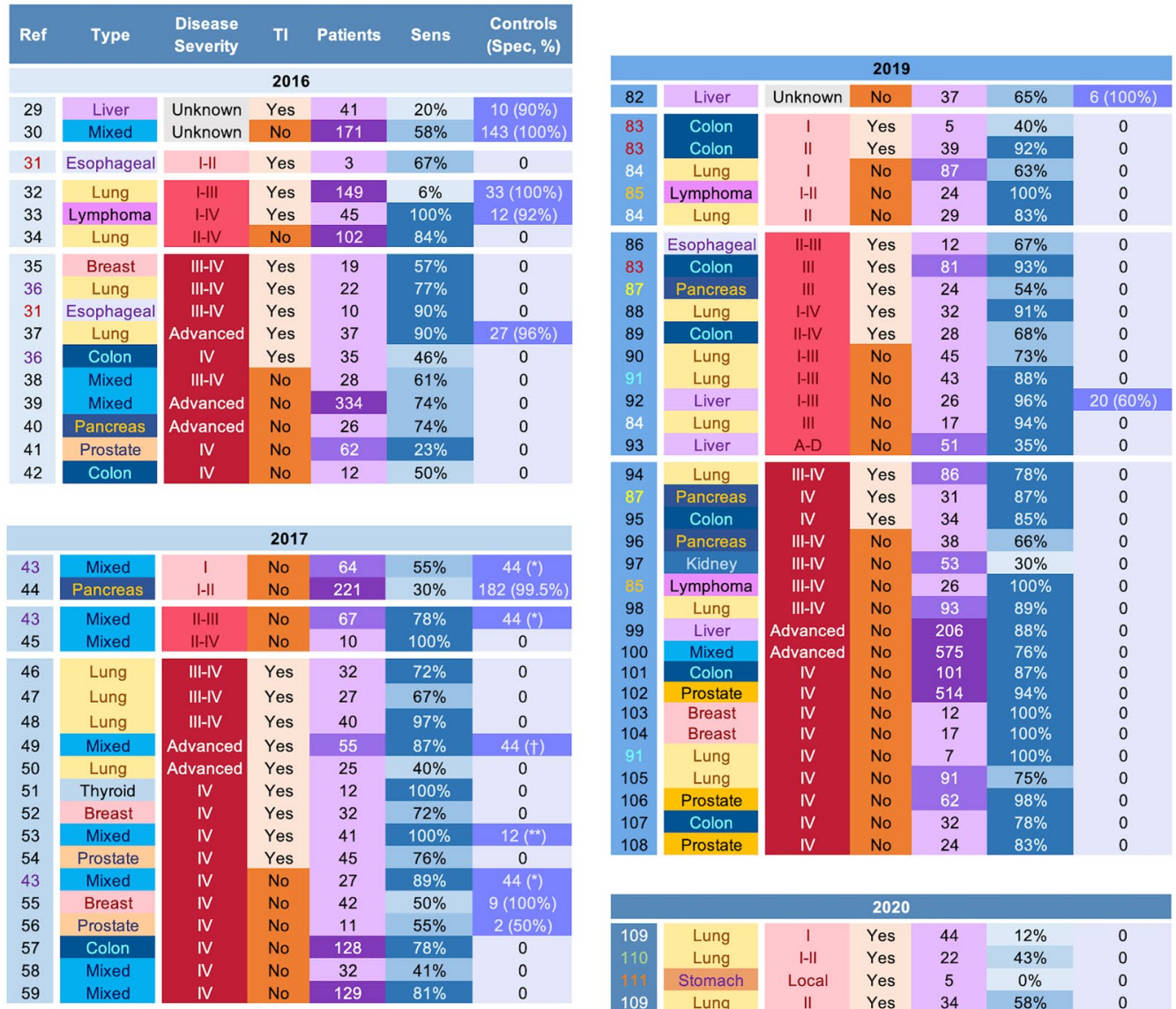

\begin{tabular}{|c|c|c|c|c|c|c|}
\hline \multicolumn{7}{|c|}{2018} \\
\hline 60 & Lung & I-II & Yes & 11 & $64 \%$ & 0 \\
\hline 61 & NB & I-IV & Yes & 19 & $100 \%$ & 0 \\
\hline 62 & Lymphoma & I-IV & Yes & 217 & $98 \%$ & 0 \\
\hline 63 & Liver & $A-D$ & Yes & 30 & $63 \%$ & 0 \\
\hline 60 & Lung & III-IV & Yes & 10 & $60 \%$ & 0 \\
\hline 63 & Liver & A-D & No & 30 & $27 \%$ & 0 \\
\hline 64 & Lung & III-IV & Yes & 45 & $91 \%$ & 0 \\
\hline 65 & Lung & III-IV & Yes & 30 & $100 \%$ & 0 \\
\hline 66 & Lung & Advanced & Yes & 77 & $96 \%$ & 0 \\
\hline 67 & Esophageal & Advanced & Yes & 21 & $14 \%$ & 0 \\
\hline 68 & Mixed & Advanced & Yes & 16 & $100 \%$ & 0 \\
\hline 69 & Lung & IV & Yes & 43 & $95 \%$ & 0 \\
\hline 70 & Lung & III-IV & No & 65 & $68 \%$ & 0 \\
\hline 71 & Melanoma & III-IV & No & 25 & $48 \%$ & 0 \\
\hline 72 & Lung & III-IV & No & 48 & $65 \%$ & 0 \\
\hline 73 & Colon & III-IV & No & 1,397 & $85 \%$ & 0 \\
\hline 74 & Mixed & Advanced & No & 21,807 & $85 \%$ & 0 \\
\hline 75 & Pancreas & IV & No & 17 & $29 \%$ & 0 \\
\hline 76 & Breast & IV & No & 34 & $29 \%$ & $15(t+)$ \\
\hline 77 & Lung & IV & No & 49 & $57 \%$ & 0 \\
\hline 78 & Prostate & IV & No & 13 & $100 \%$ & 0 \\
\hline 79 & Prostate & IV & No & 201 & $57 \%$ & 0 \\
\hline 80 & Breast & IV & No & 56 & $27 \%$ & 0 \\
\hline 81 & Colon & IV & No & 23 & $87 \%$ & 0 \\
\hline
\end{tabular}

Severity Early Intermediate Advanced

\begin{tabular}{l|r|r|r|} 
Sample Size & $<\mathbf{5 0}$ & $\mathbf{5 0 - 1 0 0}$ & $>100$ \\
\hline
\end{tabular}

\begin{tabular}{|l|l|l|l|l|}
\hline Sensitivity, $\%$ & $<25$ & $25-50$ & $50-75$ & $75-100$ \\
\hline
\end{tabular}

\begin{tabular}{|c|c|c|c|c|c|c|}
\hline \multicolumn{7}{|c|}{2020} \\
\hline 109 & Lung & 1 & Yes & 44 & $12 \%$ & 0 \\
\hline 110 & Lung & $|-| \mid$ & Yes & 22 & $43 \%$ & 0 \\
\hline 111 & Stomach & Local & Yes & 5 & $0 \%$ & 0 \\
\hline 109 & Lung & ॥ & Yes & 34 & $58 \%$ & 0 \\
\hline 112 & Lung & I & Both & 48 & $42 \%$ & 0 \\
\hline 112 & Lung & ॥ & Both & 21 & $67 \%$ & 0 \\
\hline 113 & Breast & Early & No & 206 & $63 \%$ & 0 \\
\hline 114 & Lung & II-III & Yes & 20 & $41 \%$ & 0 \\
\hline 109 & Lung & III & Yes & 30 & $56 \%$ & 0 \\
\hline 115 & Kidney & I-IV & Yes & 22 & $55 \%$ & 0 \\
\hline 116 & Colon & I-IV & Yes & 26 & $100 \%$ & 0 \\
\hline 117 & Esophageal & I-IV & Yes & 35 & $51 \%$ & 0 \\
\hline 118 & Thyroid & I-IV & Yes & 36 & $39 \%$ & 0 \\
\hline 112 & Lung & III & Both & 16 & $88 \%$ & 0 \\
\hline 119 & Colon & II-III & No & 18 & $89 \%$ & $30(100 \%)$ \\
\hline 120 & Liver & $A-C$ & No & 42 & $95 \%$ & 0 \\
\hline 121 & Mixed & I-IV & No & 176 & $67 \%$ & 0 \\
\hline 122 & Pancreas & I-IV & No & 63 & $37 \%$ & $73(97 \%)$ \\
\hline 123 & Breast & $\mathrm{I}-\mathrm{IV}$ & No & 41 & $71 \%$ & 0 \\
\hline 124 & Stomach & I-IV & No & 50 & $54 \%$ & 0 \\
\hline 125 & Breast & IIIIV & No & 35 & $86 \%$ & $20(95 \%)$ \\
\hline 126 & Lung & III-IV & Yes & 97 & $59 \%$ & 0 \\
\hline 110 & Lung & III-IV & Yes & 7 & $67 \%$ & 0 \\
\hline 127 & Lung & III-IV & Yes & 228 & $68 \%$ & 0 \\
\hline 128 & Breast & III-IV & Yes & 15 & $100 \%$ & 0 \\
\hline 129 & Mixed & Advanced & Yes & 124 & $84 \%$ & $47(100 \%)$ \\
\hline 130 & Lung & IV & Yes & 18 & $50 \%$ & $6(100 \%)$ \\
\hline 131 & Brain & IV & Yes & 11 & $0 \%$ & 0 \\
\hline 109 & Lung & IV & Yes & 22 & $74 \%$ & 0 \\
\hline & Stomach & IV & Yes & 13 & $38 \%$ & 0 \\
\hline 132 & Colon & IV & Yes & 19 & $89 \%$ & 0 \\
\hline 133 & Lung & IV & Yes & 82 & $67 \%$ & 0 \\
\hline 134 & Mixed & Advanced & No & 68 & $65 \%$ & 0 \\
\hline 135 & Mixed & IV & No & 298 & $81 \%$ & 0 \\
\hline 136 & Breast & IV & No & 56 & $73 \%$ & 0 \\
\hline 137 & Breast & IV & No & 255 & $89 \%$ & 0 \\
\hline 138 & Breast & IV & No & 40 & $100 \%$ & 0 \\
\hline 131 & Brain & IV & No & 11 & $55 \%$ & 0 \\
\hline 139 & Colon & IV & No & 17 & $100 \%$ & 0 \\
\hline 140 & Prostate & IV & No & 250 & $60 \%$ & 0 \\
\hline 141 & Breast & IV & No & 18 & $83 \%$ & 0 \\
\hline 142 & Lung & IV & No & 73 & $58 \%$ & 0 \\
\hline
\end{tabular}


4Fig. 2 Profile of publications from 2016 to 2020 using NGS for mutation-based ctDNA detection. A PubMed query ${ }^{a}$ was used to initiate a search in each year for publications with a total sample size $\geq 10$. Publications that sought to detect ctDNA associated with minimal residual disease were excluded. The list is first grouped by year (Yr), then disease severity, and finally by whether or not the mutationbased search for ctDNA was tumour informed. The reference (Ref) column identifies the citation. When feasible, data associated with different disease severities are presented separately and the reference number is non-black to support matching of data from the same source. In one study (Ref. [112]), data obtained with and without a tumour-informed search were merged and separation was not possible (marked 'Both'). Sensitivity (Sens) represents a study value corresponding to the mutation-based detection of ctDNA to determine presence/absence of a malignancy. The associated sample size is presented in the adjacent column (Patients). Specificity (Spec) is reported only if obtained from healthy control data. Sensitivity and specificity values should be interpreted cautiously as calculations can vary substantially within and between publications. For example, in Ref. [131] the authors report detection of ctDNA in 55\% of patients. However, no mutations identified in solid tumour DNA were present in ccfDNA, so sensitivity is also shown at $0 \%$ for a tumourinformed search. To gain adequate contextual understanding of values, reviewing the publication's supplemental data may be necessary. ccfDNA circulating cell-free DNA, ctDNA circulating tumour DNA, mixed $=$ cancers from different organs, $N B$ neuroblastoma. *Specificity not calculated, controls used to determine error rate $(<3.3 \times$ $10^{-7}$ false positive mutation calls per base); ${ }^{\dagger}$ controls used for error modelling; **specificity not calculated, median error rate of 0.03 non-silent single nucleotide variants per $\mathrm{Mb} ;{ }^{\dagger \dagger}$ specificity not calcu-

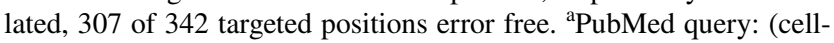
free DNA[Title]) AND (cancer) AND (("YEAR/01/01"[Date - Publication] : "YEAR/12/31"[Date - Publication]) AND (next-generation sequencing) AND (circulating))

cancers, differences in fragment length size between ctDNA and ccfDNA may represent an exploitable phenomenon to further move ccfDNA beyond research development and towards a non-invasive diagnostic tool in clinical oncology.

\section{The Fragment Length of ctDNA}

The fragment length of ctDNA was originally used to discern the type of cell death driving the release of cell-free DNA into the circulation-apoptosis versus necrosis. DNA derived from apoptosis has a characteristic ladder-like distribution with the principal peak at the length of the mononucleosome ( $167 \mathrm{bp})$ and subsequent peaks of decreasing magnitude corresponding to di- and trinucleosomes (Fig. 1b) [144]. Necrosis produces genomic DNA with lengths > $10,000 \mathrm{bp}$. Initially, there was evidence supporting the origins of ccfDNA from both pathways [145]. Terms such as apoptosis index and DNA integrity index subsequently emerged to characterize PCR-based analyses using ratios of short and long amplicon lengths [146-148]. By 2011, there was a preponderance of evidence that ccfDNA originated from apoptosis. The first application of NGS to better characterize ctDNA fragment length occurred in 2015, when
Jiang et al. used copy number aberrations in hepatocellular carcinoma to infer the difference in size distributions between ccfDNA and ctDNA [149]. A positive correlation was identified between the tumour DNA fraction in plasma and the proportion of DNA fragments less than $150 \mathrm{bp}$, suggesting a shorter size length profile for ctDNA compared to the mononucleosome's 167-bp length associated with normal ccfDNA.

In 2016, two technical aspects of NGS were used to characterize the specific fragment length of ctDNA. First, during library preparation of ccfDNA, mechanical and enzymatic shearing is not used because the predominant component of ccfDNA is found in association with the mononucleosome, which has a median length of $\sim 167 \mathrm{bp}$ (Fig. 1b). Therefore, to prevent generation of short fragments that are difficult to sequence, ccfDNA NGS workflows do not include a DNA shearing step, which is commonly used during preparation of genomic DNA extracted from white blood cells and tumour cells. Second, NGS generally employs a constrained sequencing length (e.g. 100 bp, 125 bp, 150 bp), which means the entire length of the ccfDNA molecule may not be sequenced. Thus, many NGS applications use paired-end sequencing to read the sequence from both ends of the molecule. Once paired reads are aligned to a reference genome, the length of the original DNA molecule is measured. These two components of NGS were combined with rat xenograft models of a brain tumour and hepatocellular carcinoma to precisely measure fragment lengths of normal ccfDNA and ctDNA, which were parsed based on species (rat DNA vs. human DNA, respectively) [150]. Overall, the median fragment length of ctDNA was 134-144 bp, which was 20-30 bp shorter than the median length of $167 \mathrm{bp}$ for rat ccfDNA (Fig. 1c). In addition, smaller peaks along the overall fragment distribution profile of the mononucleosome were present at regular intervals (i.e. 10-bp periodicity). Observations regarding differences in fragment length size and, to a lesser extent, periodicity translated to a patient with widely metastatic melanoma where the principal peak associated with the BRAF p.V600E mutation was 20 bp shorter than the wild type distribution. Similar differences in fragment size were also observed in lung cancer patients harbouring the common EGFR p.T790M and p.L858R mutations. These findings not only solidified observations by Jiang et al. [149], but also echoed findings from several earlier reports. First, Giacona et al. applied a microspreading technique in 1998 to measure double-stranded DNA with transmission electron microscopy to compare strand length between three controls and three patients with adenocarcinoma of the pancreas [151]. The median ccfDNA strand length in cancer patients was $185 \mathrm{~nm}$ compared to $273 \mathrm{~nm}$ in controls, which is a 30-bp difference (assuming $0.34 \mathrm{~nm} / \mathrm{bp}$ ). Second, in 2010, Lo et al. used NGS to describe characteristics of foetal ccfDNA in the maternal circulation [152]. The principal 
a

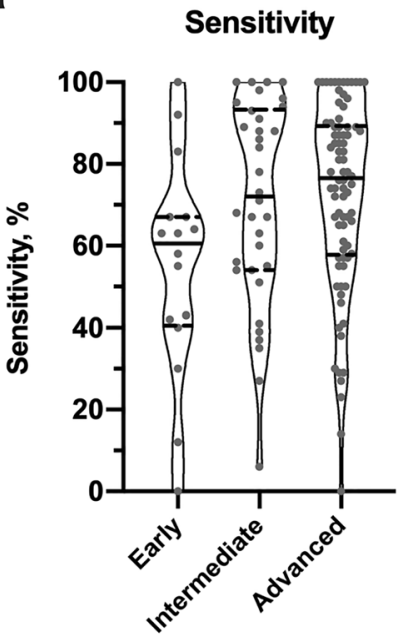

b

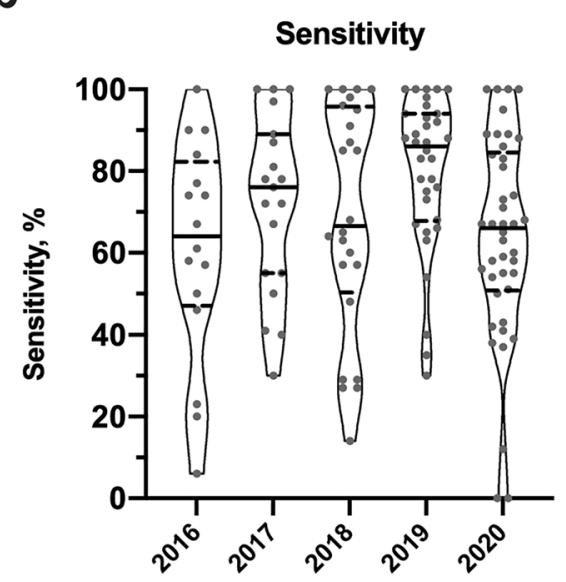

C

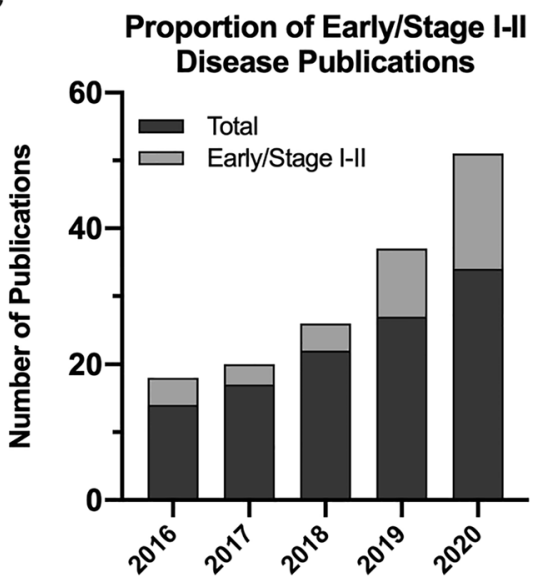

Fig. 3 Characteristics of publications from 2016 to 2020 using NGS for mutation-based ctDNA detection. In a, the violin plots show the sensitivity of mutation-based ctDNA detection relative to disease severity. In general, there was a trend towards increased detection with more severe disease. In $\mathbf{b}$, sensitivity is relatively similar across years likely because more difficult to detect tumours are being included in later years, which may adversely affect sensitivity but also indicates detection strategies are working towards inclusion of more

fragment length of foetal ccfDNA in the maternal circulation was $143 \mathrm{bp}$, shorter than the principal fragment length of maternal ccfDNA at $166 \mathrm{bp}$. In addition, the fragment distribution for both foetal and maternal ccfDNA exhibited a 10-bp periodicity. Finally, Zheng et al. showed in 2012 that ccfDNA derived from a transplanted liver exhibited a 10-bp periodicity consisting of significantly shorter fragments than that of the recipient-specific ones [153]. Collectively, these studies established and provided orthogonal support for the narrow difference in fragment size length between ctDNA and ccfDNA. Importantly, multiple studies using a mixture of xenograft models and point mutations have subsequently confirmed the discrete size disparity between ctDNA and ccfDNA [68, 112, 121, 154, 155], which has also been the topic of previous reviews [156]. In addition, the overall size profile in patients with metastatic disease has also been shown to be shorter compared to healthy controls [154], but substantial overlap between patients and controls limits size profiling alone as a clinical diagnostic tool, particularly for early-stage and non-metastatic cancers. Although the origins of the 10-bp periodicity seen in the fragmentation pattern of ccfDNA has been linked to both intra- and extracellular processes $[157,158]$, the origins of the size difference between ctDNA and ccfDNA is unclear. However, there is compelling evidence that chromatin structure or epigenetic changes may have a role [15, 159-161] (see [162] for a review of epigenetic modifications associated with ccfDNA). Regardless of aetiology, the focus of this review is exploring prior use of challenging cancers. In $\mathbf{c}$, the total number of publications profiled for each year from Fig. 2 is shown (dark gray) and the number of those publications that include early/stage I-II disease is also depicted (light gray). In more recent years, a larger proportion of publications are seeking to detect ctDNA in early-stage and non-metastatic cancers. $c t D N A$ circulating tumour DNA, NGS next-generation sequencing

ctDNA fragment length to improve the non-invasive detection of somatic mutations in ccfDNA associated with malignant disease. Both in vitro and in silico methods to isolate subfractions of ccfDNA are reviewed to identify strengths and weaknesses associated with different approaches. In so doing, the goal if this review is to establish the current state of the art in ccfDNA size-selection technology to better understand the necessary steps forward to potentially bring ccfDNA diagnostics to earlier stages of disease and enable precision oncology through detection of patient-specific somatic mutations regardless of disease severity.

\section{In Vitro Enrichment of ctDNA}

In vitro refers to a mechanical or wet laboratory-based technique. Gel-based methods have been the principal in vitro approach for extracting a narrow size profile range. The first description of this occurred in 2016 and used polyacrylamide gel electrophoresis to achieve sufficient resolution to obtain six fractions from the ccfDNA mononucleosome peak [150]. In four lung cancer patients harbouring the EGFR p.T790M mutation, isolation of the ccfDNA fraction 20-50 bp shorter than the principal peak increased the mutant allele frequency (MAF) measured by droplet digital PCR by 2.8fold to 9.1-fold in $75 \%$ of samples (Table 1). Although the size-selection methodology was not scalable to broader 
Table 1. In vitro size selection for ctDNA detection

\begin{tabular}{|c|c|c|c|c|}
\hline Publication & Methods & $\begin{array}{l}\text { Cancer (sample } \\
\text { size) }\end{array}$ & $\begin{array}{l}\text { Baseline detection charac- } \\
\text { teristics }\end{array}$ & Results \\
\hline $\begin{array}{l}\text { Underhill et al., } \\
2016[150]\end{array}$ & $\begin{array}{l}\text { PAGE with manual excision to } \\
\text { extract six fractions from the } \\
\text { mononucleosome after library } \\
\text { generation and PCR amplifi- } \\
\text { cation } \\
\text { ddPCR used to measure MAF }\end{array}$ & Lung $(N=4)$ & $\begin{array}{l}E G F R \text { T790M MAF range } \\
\text { in ccfDNA } 0.33-7.1 \%\end{array}$ & $\begin{array}{l}\text { 1.1- to } 9.1 \text {-fold enrichment of } E G F R \\
\text { p.T790M mutations in ccfDNA } \\
\text { fraction 20-50 bp shorter than the } \\
\text { mononucleosome peak } \\
\text { The sample with a MAF of } 0.33 \% \\
\text { showed strongest enrichment at } \\
\text { 9.1-fold }\end{array}$ \\
\hline \multirow[t]{3}{*}{$\begin{array}{l}\text { Mouliere et al., } \\
2018 \text { [68] }\end{array}$} & $\begin{array}{l}\text { 3.0\% agarose cassette target- } \\
\text { ing a single ccfDNA fraction } \\
\text { ( } 90-150 \mathrm{bp} \text { ) prior to library } \\
\text { generation and PCR amplifi- } \\
\text { cation } \\
\text { sWGS to calculate tMAD scores }\end{array}$ & $\begin{array}{l}\text { HGSOC }(N=35 ; \\
\quad 48 \text { samples }) \\
\text { Healthy controls }(N \\
=46 ; 65 \text { samples })\end{array}$ & $\begin{array}{l}\text { Median tMAD score of } \\
0.015 \text { in patients (mean of } \\
0.05 \text {; range } 0.005-0.30 \text { ) } \\
\text { Median tMAD score of } \\
0.01 \text { in controls (range } \\
0.004-0.015 \text { ) } \\
50 \% \text { of patients had an } \\
\text { increased tMAD score } \\
\text { compared to controls }\end{array}$ & $\begin{array}{l}\text { 0.9- to 6.4-fold enrichment of tMAD } \\
\text { scores (mean of } 2.5 \text {-fold and } \\
\text { median of } 2.1 \text {-fold enrichment) } \\
\text { After size selection in } 48 \text { patient } \\
\text { samples and } 18 \text { control samples, } \\
82 \% \text { of samples had an increased } \\
\text { tMAD score compared to controls } \\
\text { tMAD scores increased } \geq 2 \text {-fold after } \\
\text { size selection in } 54.3 \% \text { (19/35) } \\
\text { and } 22.2 \%(4 / 18) \text { of pre-treatment } \\
\text { patients and controls, respectively }\end{array}$ \\
\hline & $\begin{array}{l}\text { 3.0\% agarose cassette target- } \\
\text { ing a single ccfDNA fraction } \\
(90-150 \text { bp) prior to library } \\
\text { generation and PCR amplifi- } \\
\text { cation } \\
\text { WES for point mutations }\end{array}$ & $\begin{array}{r}\operatorname{HGSOC}(N=6 ; \\
\text { pre-treatment })\end{array}$ & $\begin{array}{l}821 \text { mutations identified } \\
\text { in } 6 \text { patients, with mean } \\
\text { MAF of } 12.0 \% \text { (median of } \\
9.5 \% \text {, range } 0.53-100 \% \text { ) }\end{array}$ & $\begin{array}{l}\text { Mean increase in MAF of } 4.19 \text {-fold } \\
\text { (median } 4.27 \text {-fold increase) } \\
\text { In } 5 \text { of } 6 \text { patients, size selection iden- } \\
\text { tified an additional } 171 \text { mutations } \\
\text { with mean MAF of } 27.9 \% \text { (median } \\
\text { of } 25 \% \text {, range } 8.3-75 \% \text { ) }\end{array}$ \\
\hline & & $\begin{array}{r}\operatorname{HGSOC}(N=6 ; \\
\text { post-treatment })\end{array}$ & $\begin{array}{l}202 \text { mutations identified } \\
\text { in } 6 \text { patients, with mean } \\
\text { MAF of } 8.1 \% \text { (median of } \\
6.5 \% \text {, range } 1.2-47.6 \% \text { ) }\end{array}$ & $\begin{array}{l}\text { Mean increase of } 2.1 \text {-fold (median } \\
1.5 \text {-fold, range } 0.9 \text { - to } 11 \text {-fold) } \\
\text { In } 4 \text { of } 6 \text { patients, size selection iden- } \\
\text { tified an additional } 89 \text { mutations, } \\
\text { with mean MAF of } 39.3 \% \text { (median } \\
37.5 \% \text {, range } 15.4-100 \% \text { ) }\end{array}$ \\
\hline $\begin{array}{l}\text { Hellwig et al., } \\
2018 \text { [155] }\end{array}$ & $\begin{array}{l}\text { Automated liquid handler using } \\
\text { a } 3.0 \% \text { agarose matrix in a } \\
\text { 12-channel cassette to extract } \\
3 \text { fractions after library gen- } \\
\text { eration and PCR amplification } \\
\text { ddPCR } \\
\text { Capture-enrichment panel }\end{array}$ & $\begin{array}{l}\text { Melanoma }(N=8) \\
\text { colorectal adeno- } \\
\text { carcinoma }(N= \\
\text { 3), pancreatic } \\
\text { adenocarcinoma } \\
(N=2)\end{array}$ & $\begin{array}{l}\text { All samples were posi- } \\
\text { tive for point mutations } \\
\text { in } K R A S \text { or } B R A F \text { by } \\
\text { ddPCR, with a mean } \\
\text { MAF of } 2.4 \% \text { (median of } \\
1.1 \% \text {, range } 0.39-12.3 \% \text { ) }\end{array}$ & $\begin{array}{l}\text { At a median insert size of } 141 \mathrm{bp} \text {, } \\
\text { MAFs were enriched on average } \\
\text { by } 2.9 \text {-fold (median } 2.5 \text {-fold, range } \\
0.2-10.3 \text { ) as measured by ddPCR } \\
\text { At a median insert size of } 141 \mathrm{bp} \text {, } \\
\text { MAFs were enriched on average by } \\
2.0 \text {-fold (median of } 2.0 \text {-fold, range } \\
0.8-3.3 \text { ) as measured by NGS } \\
\text { At median insert size of } 167 \mathrm{bp}, \\
\text { MAFs were reduced by a median of } \\
0.8 \text { and } 0.7 \text {-fold using ddPCR and } \\
\text { NGS, respectively } \\
\text { MAF measured by ddPCR and NGS } \\
\text { were strongly correlated (Pearson's } \\
r=0.97, P<0.001 \text { ) }\end{array}$ \\
\hline $\begin{array}{l}\text { Ishida et al., } 2020 \\
\text { [116] }\end{array}$ & $\begin{array}{l}\text { SPRIselect beads to obtain } \\
\text { fractionated small ccfDNA } \\
(100-400 \mathrm{bp}) \\
\text { dPCR } \\
\text { Hotspot amplicon-based } \\
\text { sequencing in } 50 \text { genes }\end{array}$ & $\begin{array}{l}\text { Colorectal cancer } \\
(N=26 ; \text { stage } \\
\text { I-II, } N=6 ; \text { stage } \\
\text { III-IV, } N=20)\end{array}$ & $\begin{array}{l}K R A S, B R A F, \text { and } T P 53 \\
\text { mutations present in } \\
\text { tumour DNA were } \\
\text { detected in serum by } \\
\text { dPCR in } 24 \text { of } 26 \text { patients } \\
\text { (92.3\%), with a mean } \\
\text { MAF of } 11.7 \% \text { (median of } \\
1.2 \% \text {, range } 0.1-63.4 \% \text { ) }\end{array}$ & $\begin{array}{l}\text { Size selection increased mean MAFs } \\
\text { of driver genes by dPCR from } 6.8 \% \\
\text { to } 10.7 \% \\
\text { Size selection increased mean MAFs } \\
\text { by NGS from } 16.3 \% \text { to } 18.8 \% \\
\text { For MAFs }>1 \%, \text { NGS detected a } \\
\text { higher average number of muta- } \\
\text { tions in size-selected small ccfDNA } \\
\text { compared to unselected ccfDNA } \\
\text { (1.8 vs. } 1.0 \text { per case, respectively) }\end{array}$ \\
\hline
\end{tabular}

$c c f D N A$ circulating cell-free DNA, $c t D N A$ circulating tumour DNA, $d P C R$ digital PCR, $d d P C R$ droplet dPCR, HGSOC high-grade serous ovarian carcinoma, $M A F$ mutant allele frequency, $N G S$ next-generation sequencing, $P A G E$ polyacrylamide gel electrophoresis, $P C R$ polymerase chain reaction, $s W G S$ shallow whole genome sequencing, $t M A D$ trimmed median absolute deviation from copy number neutrality, WES whole exome sequencing 
applications, the potential for using the size difference to enrich for ctDNA was successfully demonstrated.

In 2018, in vitro size selection was applied to larger sample sizes using benchtop microfluidic devices. Mouliere et al. loaded 8-20 ng of pre-library ccfDNA (i.e. ccfDNA prior to library generation and PCR amplification) into a 3\% agarose cassette (HTC3010, Sage Bioscience) and targeted the ccfDNA fraction between 90 and $150 \mathrm{bp}$ for extraction on a PippinHT (Sage Bioscience; Table 1) [68]. Using shallow whole genome sequencing (sWGS) (read depth of 0.5 $\times$ ), the trimmed median absolute deviation from copy number neutrality (tMAD; a measure of copy number alterations) increased by a median of 2.1-fold in 47 of 48 plasma samples from 35 patients with high-grade serous ovarian cancer. In a subset of six patients with ctDNA variants detected by whole exome sequencing (WES) (median MAF 9.5\%, range $0.5-100 \%$ ), in vitro size selection increased MAF by a median factor of 4.27-fold. Three weeks after therapy when MAFs were reduced (median MAF 6.5\%, range 1.2-48\%), the median increase in MAF via in vitro size selection was less, at 1.5-fold, suggesting that in vitro size selection may have reduced benefits at lower MAFs.

Instead of using ccfDNA during size selection prior to library preparation, Hellwig et al. used $1 \mu \mathrm{g}$ of ccfDNA obtained after library generation and PCR amplification as input into an automated liquid handler (NIMBUS Select, Hamilton, Reno, NV) that incorporated Ranger Technology (Coastal Genomics, Burnaby, BC) for the monitoring and real-time manipulation of electrophoretic mobilities through a 3.0\% agarose matrix in a 12-channel cassette (Table 1) [155]. Three ccfDNA fractions centred at $\sim 141 \mathrm{bp}, \sim 155$ bp, and $\sim 167 \mathrm{bp}$ were obtained from 13 patients harbouring mutations in a BRAF p.V600, KRAS p.G12, or KRAS p.G13 codon associated with colorectal cancer, melanoma, and pancreatic cancer for comparison to unselected ccfDNA. The median MAF in unselected ccfDNA was $1.1 \%$ (range $0.39-12.3 \%$ ), with MAF $\leq 0.81 \%$ in $46.2 \%$ of the mutations. Using NGS, an average 2.0-fold increase in MAF was observed in the fraction centred at $141 \mathrm{bp}$ compared to unselected ccfDNA, which was significantly higher than the 1.3fold gain in the 155-bp fraction and the 0.7 -fold reduction in the 167-bp fraction. All NGS results were cross-validated with droplet digital PCR, which similarly confirmed enrichment of ctDNA through in vitro size selection. In addition, the observed enrichment of ctDNA associated with a low MAF $(<1 \%)$ suggests that size selection conducted on ccfDNA libraries rather than pre-library ccfDNA may be advantageous by mitigating loss of rare unique molecules through PCR amplification to generate more copies for acquisition.

Most recently, Ishida et al. used solid-phase reversible immobilization (SPRI) beads (SPRIselect beads, Beckman Coulter, CA) to fractionate pre-library ccfDNA to obtain
DNA sizes of 100-400 bp (Table 1) [116]. In so doing, the proportion of ccfDNA in the range of 90-150 bp increased from $3.0 \%$ in unselected ccfDNA to $25.9 \%$ in the sizeselected ccfDNA. In 20 patients with colorectal cancer $(63 \%$ with distant metastasis), the mean MAFs of driver genes as measured by digital PCR increased from $6.8 \%$ in unselected ccfDNA to $10.7 \%$ in size-selected ccfDNA. Using NGS, a similar increase in mean MAFs was observed. In addition, the average number of mutations with an MAF $>1 \%$ detected in size-selected ccfDNA compared to unselected ccfDNA increased from 1.0 to 1.8 per patient. In contrast to gel-based techniques that sought to isolate a subfraction of the mononucleosome, the bead-based approach yielded a size-selected fraction of ccfDNA inclusive of both the mono- and dinucleosomes. Although the extent of ctDNA enrichment was less than the gel-based methods, the study demonstrated that even a marginal shift in the overall size profile of ccfDNA towards shorter fragment lengths has the potential to improve ctDNA detection, which may have implications for high-throughput labs using bead-based methods as part of automated protocols.

Additional publications that use in vitro size selection to enrich for ctDNA were not identified in the literature. However, in vitro size selection has been more extensively investigated in prenatal diagnostics, where foetal ccfDNA in the maternal circulation has a similar fragment length shortening relative to maternal ccfDNA [152]. Thus, several papers are highlighted herein to substantiate the observations described above and to also provide a broader scope of in vitro methods associated with ccfDNA size selection that may have potential ctDNA applications. The in vitro methodologies to enrich for foetal ccfDNA from maternal ccfDNA broadly organize into two categories: (1) isolation of the entire mononucleosome or (2) extraction of the shorter fragments associated with the mononucleosome. Regarding the former category, Hahn et al. described a microsystem to preconcentrate ccfDNA using electrokinetic trapping followed by separation of fragments using ionic mobility to effectively parse ccfDNA with a length $<$ 300 bp from fragments $>500$ bp [163]. Yang et al. established a PCR-based enrichment protocol by modifying the amplification reaction conditions [164]. Using an optimized lower denaturing temperature that biased PCR towards amplification of shorter fragments, the foetal fraction was comparably increased to that of removing fragments longer than $300 \mathrm{bp}$ from the maternal ccfDNA sample. A potential advantage of this method is that existing workflows do not require alterations beyond optimization of thermal cycling temperatures. To isolate the short fraction $(<160 \mathrm{bp})$ of cell-free DNA from the mononucleosome, $\mathrm{Hu}$ et al. used custom-designed magnetic beads with an average particle size of $1 \mu \mathrm{m}$ (for reference, the average size of the industry standard SPRI beads is similarly $1 \mu \mathrm{m}$ [165]) to enrich for 
the foetal fraction of ccfDNA [166]. Using a bead ratio of $1.5 \times$ for size selection after end-repair and prior to adapter ligation increased the proportion of ccfDNA $<160 \mathrm{bp}$ from $\sim 25 \%$ in unfractionated ccfDNA to $\sim 85 \%$ in fractionated ccfDNA. Foetal ccfDNA was enriched in the fractionated maternal ccfDNA by 1.5- to 4-fold, which improved detection of missed foetal trisomies by $45.5 \%$. Compared to the approach by Ishida et al. described above [116], the method employed by $\mathrm{Hu}$ et al. appears to more strongly select for the shorter fraction of the mononucleosome, suggesting that a bead-based approach may be able to more strongly enrich for ctDNA once optimized. Most recently, Welker et al. used gel electrophoresis on 2\% agarose cassettes (BluePippin, Sage Bioscience) to isolate short ccfDNA fragments from the mononucleosome with an average length of $140 \mathrm{bp}$ (not including adapters) [167]. Of the 2401 maternal ccfDNA samples tested, 2395 (99.8\%) showed an increase in the foetal fraction, with an average increase of 2.3-fold. Samples with a foetal fraction $<4 \%$ showed the largest gain, with an average increase of 3.9-fold. Because the general methodology was similar to that used by Mouliere et al. [68] and Hellwig et al. [155] for ctDNA enrichment, an important aspect to recognize in the Welker et al. study [167] is the feasibility of scaling gel-based techniques to meet highthroughput demands.

Overall, there is compelling evidence that in vitro size selection enriches for ctDNA. The brief overview of a few foetal ccfDNA studies supports this conjecture, while also identifying additional in vitro strategies that may facilitate ccfDNA diagnostics in cancer. A key caveat to recognize, however, is the limited enrichment data for MAF < $1 \%$. Moreover, data have not been previously reported for in vitro enrichment of ctDNA associated with an MAF < $0.1 \%$. Thus, additional studies are necessary to determine if the strengths of in vitro fragment size selection to enrich for ctDNA extend to the lower allele frequencies that are more representative of early-stage and non-metastatic disease.

\section{In Silico Applications of ctDNA Fragment Length}

In silico refers to the computer-based or bioinformatic curation of NGS data. Because paired-end sequencing associated with NGS enables strand length measurements, reads can be sorted based on the length of the original DNA molecules used during library preparations. In 2018, Mouliere et al. applied an in silico size-selection analysis to synthetically enrich for ctDNA by selecting for ccfDNA fragments with lengths of 90-150 bp (Table 2) [68]. In 189 cancer patients and 65 healthy controls, in silico size selection of sWGS data improved the area under the curve (AUC) for discerning cancer patients based on tMAD scores from
0.69 to 0.90 . In silico size selection also increased MAF as measured by WES by 2.2-fold in six patients with highgrade serous ovarian carcinoma. In a separate cohort of 16 cancer patients that underwent WES, in silico size selection increased the MAF of ctDNA on average by 1.7 -fold and additional mutations were detected in 13 of 16 patients. In 2020, Smith et al. used in silico size selection for ccfDNA fragments between 90 and 150 bp to improve detection of ctDNA associated with renal tumours (Table 2) [115]. In silico size profiling improved somatic copy number alteration (SCNA) detection in ctDNA from 6.3 to $22.9 \%$ in 48 patients with renal tumours ranging from benign tumours to metastatic malignancies. In a separate cohort of 43 patients with renal cell carcinoma (41 with metastatic disease) and most with the primary tumour removed (35/43 patients), in silico size selection identified SCNA-based ctDNA in six additional patients, increasing the detection rate from 18.6 to $32.6 \%$. The original MAFs of SCNAs ranged from 4 to $17 \%$ and increased on average by 2.2 -fold (range 0.9-5.7). Also in 2020, Nygard et al. similarly used in silico size selection for ccfDNA fragments between 90 and $150 \mathrm{bp}$ to improve SCNA-based detection of ctDNA derived from stage III non-small cell lung cancer (Table 2) [168]. In 23 samples obtained from six patients undergoing radiation therapy, in silico size selection improved SCNA detection from 22 to $70 \%$ of samples. Although it is important to recognize that these three studies largely identified ctDNA associated with MAFs $>1 \%[68,115,168]$, this MAF range was governed by study design rather than technical limitations of in silico size selection. The studies were either targeting SCNA via sWGS or point mutations detected by WES. Both approaches are associated with read depths that are not amenable to detection of MAFs $<1 \%$. Thus, the use of in silico size selection to improve detection of specific variants in ctDNA at low MAFs remains uncertain. However, these studies collectively provide compelling evidence that integration of size profiling into bioinformatic applications of ctDNA detection may be advantageous.

As an alternative to the explicit exclusion of fragments outside of a size profile window, in silico approaches have also assigned a weight based on fragment length as part of a probability model for cancer detection. Using sWGS data and tMAD scores, Mouliere et al. applied a random forest algorithm that included the proportion of fragments in defined size ranges to enhance the detection of tumours [68] (Table 3). In 68 patients with high ctDNA cancers, the model was able to distinguish cancer patients from 26 healthy controls with an AUC of 0.994. In 57 patients with low ctDNA cancers, the AUC was 0.914. Notably, using fragmentation features without the tMAD score yielded AUCs of 0.989 and 0.891 , respectively, suggesting that fragment size was the principal component of the original model. Wan et al. used fragment length as part of an in 
Table 2. In silico size-based filtering of insert size for ctDNA detection

\begin{tabular}{|c|c|c|c|c|}
\hline Publication & Methods & Cancer (sample size) & $\begin{array}{l}\text { Baseline detection charac- } \\
\text { teristics }\end{array}$ & Results \\
\hline \multirow[t]{4}{*}{$\begin{array}{l}\text { Mouliere et al., } \\
2018 \text { [68] }\end{array}$} & $\begin{array}{l}\text { sWGS to calculate tMAD } \\
\text { scores } \\
\text { Size selection for inserts } \\
\text { with lengths of } 90-150 \mathrm{bp}\end{array}$ & $\begin{array}{l}\text { "High ctDNA" cancers from } \\
\text { melanoma, ovarian, lung, } \\
\text { colorectal, cholangiocarci- } \\
\text { noma, and other }(N=189) \\
\text { Healthy controls }(N=65)\end{array}$ & $\mathrm{AUC}=0.69$ & $\begin{array}{l}\text { After size selection, AUC } \\
\text { increase to } 0.90\end{array}$ \\
\hline & $\begin{array}{l}\text { WES for point mutations } \\
\text { Size selection for inserts } \\
\text { with lengths of } 90-150 \mathrm{bp}\end{array}$ & $\begin{array}{l}\text { HGSOC }(N=6 \text {; pre-treat- } \\
\text { ment) }\end{array}$ & $\begin{array}{l}821 \text { mutations identified in } 6 \\
\text { patients, with mean MAF } \\
\text { of } 12.0 \% \text { (median of } 9.5 \%, \\
\text { range } 0.53-100 \% \text { ) }\end{array}$ & $\begin{array}{l}\text { Mean increase in MAF of 2.2- } \\
\text { fold (median } 2.25 \text {-fold increase) } \\
\text { In } 6 \text { of } 6 \text { patients, size selection } \\
\text { identified an additional } 188 \\
\text { mutations, with mean MAF of } \\
21.5 \% \text { (median of } 16.9 \% \text {, range } \\
3.0-88.9 \% \text { ) }\end{array}$ \\
\hline & & $\begin{array}{l}\operatorname{HGSOC}(N=6 \text {; post- } \\
\text { treatment })\end{array}$ & $\begin{array}{l}202 \text { mutations identified in } 6 \\
\text { patients, with mean MAF } \\
\text { of } 8.1 \% \text { (median of } 6.5 \%, \\
\text { range } 1.2-47.6 \% \text { ) }\end{array}$ & $\begin{array}{l}\text { In } 6 \text { of } 6 \text { patients, size selection } \\
\text { identified an additional } 122 \\
\text { mutations, with mean MAF of } \\
30.3 \% \text { (median of } 25.0 \% \text {, range } \\
7.3-85.7 \% \text { ) }\end{array}$ \\
\hline & & $\begin{array}{l}\text { Colorectal, cholangiocar- } \\
\text { cinoma pancreatic, and } \\
\text { prostate }(N=16)\end{array}$ & $\begin{array}{l}2133 \text { mutations in plasma } \\
\text { with matched mutations in } \\
\text { tumour DNA (MAF range } \\
\sim 1 \% \text { to } \sim 70 \% \text { ) }\end{array}$ & $\begin{array}{l}\text { Size selection increased mean } \\
\text { MAF by } 1.7 \text {-fold in } 97 \% \text { of } \\
\text { mutations } \\
\text { In } 13 \text { of } 16 \text { patients, size selection } \\
\text { identified additional mutations }\end{array}$ \\
\hline \multirow[t]{2}{*}{$\begin{array}{l}\text { Smith et al., } \\
2020 \text { [115] }\end{array}$} & $\begin{array}{l}\text { sWGS to detect SCNAs } \\
\text { based on tMAD score } \\
\text { Size selection for inserts } \\
\text { with lengths of } 90-150 \mathrm{bp}\end{array}$ & $\begin{array}{l}\text { Renal tumours (benign to } \\
\text { metastatic; } N=48 \text { ) }\end{array}$ & $\begin{array}{l}\text { SCNA detected in } 4 \text { of } 48 \\
(6.3 \%) \text { samples }\end{array}$ & $\begin{array}{l}\text { After size selection, } 41 \text { of } 48 \\
\text { samples met criteria for tMAD } \\
\text { analysis ( }>2 \text { million reads) } \\
\text { Average tMAD score increased } \\
\text { 2.2-fold (range } 1.25-4.83 \text { ) } \\
\text { SCNA-based ctDNA detected } \\
\text { in } 8 \text { additional patients ( } 11 / 48 \text {, } \\
22.9 \% \text { ) }\end{array}$ \\
\hline & & $\begin{array}{l}\text { RCC, } N=43,41 \text { patients } \\
\text { with metastatic disease, } \\
35 \text { patients with primary } \\
\text { tumour removed }\end{array}$ & $\begin{array}{l}\text { SCNA detected in } 8 \text { of } 43 \\
\text { samples (18.6\%), with } \\
\text { median MAF of } 7 \% \text { (range } \\
4-17 \% \text { ) }\end{array}$ & $\begin{array}{l}\text { SCNA detection increased to } 14 \\
\text { of } 43 \text { samples ( } 32.6 \% \text { ) } \\
\text { MAF increased by a mean of } 2.2- \\
\text { fold (range } 0.9-5.7 \text { ) to a median } \\
\text { of } 8 \% \text { (range } 4-23 \% \text { ) }\end{array}$ \\
\hline $\begin{array}{l}\text { Nygard et al., } \\
2020 \text { [168] }\end{array}$ & $\begin{array}{l}\text { sWGS to detect SCNAs } \\
\text { based on tMAD score } \\
\text { Size selection for inserts } \\
\text { with lengths of } 90-150 \mathrm{bp}\end{array}$ & $\begin{array}{l}\text { Inoperable, stage III NSCLC } \\
\quad(N=6 ; 23 \text { samples })\end{array}$ & $\begin{array}{l}\text { SCNA detection in } 5(22 \%) \\
\text { samples from } 3 \text { of } 6 \\
\text { patients }\end{array}$ & $\begin{array}{l}\text { SCNA detection increased to } 16 \\
\text { of } 23 \text { samples ( } 70 \% \text { ) from } 6 \text { of } \\
6 \text { patients }\end{array}$ \\
\hline
\end{tabular}

$A U C$ area under the curve, $c t D N A$ circulating tumour DNA, HGSOC high-grade serous ovarian carcinoma, MAF mutant allele frequency, $N S C L C$ non-small cell lung cancer, $R C C$ renal cell carcinoma, SCNA somatic copy number alteration, $s W G S$ shallow whole genome sequencing, $t M A D$ trimmed median absolute deviation from copy number neutrality, WES whole exome sequencing

silico error reduction strategy named INtegration of VAriant Reads (INVAR), which weights mutant reads across all patient-specific mutation loci based on the empirical distribution of mutant fragments in all other samples in the cohort being studied to give a size range enriched in cancer greater weight (Table 3) [121]. Using a tumour-informed search to guide ctDNA detection, INVAR achieved a median AUC of 0.80 (range 0.64-0.92) in early-stage disease and previously difficult to detect cancers such as stage I-III nonsmall cell lung cancer, stage I-II breast cancer, and renal and brain tumours, and after surgery for stage II-III melanoma. INVAR has also been applied by Smith et al. to detect renal tumours (Table 3) [115]. Using a tumour-informed search, ctDNA was detected in 12 of 22 patients $(54.5 \%)$ with renal tumours ranging from benign to metastatic. In a search without a priori knowledge of somatic tumour mutations, INVAR detected ctDNA in $18.6 \%$ of patients with largely advanced renal cell carcinoma. Finally, Chabon et al. similarly integrated fragment length into a noise reduction strategy, an enhanced version of CAPP-Seq [37], to detect ctDNA derived from stage I-III non-small cell lung cancer (Table 3) [112]. Using a tumour-informed search, ctDNA was detected in $45 \%$ (38 of 85 ) of patients. In a subset of the 85-patient cohort where ctDNA was not detected, 
Table 3. In silico size-based weighting of potential somatic mutations for ctDNA and tumour detection

\begin{tabular}{|c|c|}
\hline Publication & Methods \\
\hline $\begin{array}{c}\text { Mouliere et al., } \\
2018 \text { [68] }\end{array}$ & $\begin{array}{l}\text { sWGS } \\
\text { RF algorithm that included proportion } \\
\text { of fragments in defined size ranges and } \\
\text { tMAD score }\end{array}$ \\
\hline
\end{tabular}

Cancer (sample size) Results

"High ctDNA" cancers from melanoma, ovarian, lung, colorectal, cholangiocarcinoma, and other $(N=68)$

"Low ctDNA" cancers from renal, brain, bladder, and pancreas $(N=57)$

Healthy controls $(N=26)$

Stage II-III melanoma after complete resection $(N=38)$

Wan et al., 2020 [121]

Tumour-informed, patient-specific, custom-capture panels

INVAR weights mutant reads across all patient-specific mutation loci based on the empirical distribution of mutant fragments in all other samples in the cohort being studied to give a size range enriched in cancer greater weight

Stage IV melanoma $(N=9 ; 52$ samples)
Stage I-IV breast cancer $(N=7)$ $\operatorname{NSCLC}(N=19)$

Renal tumours $(N=24)$

Brain tumours $(N=8)$

Renal tumours (benign to metastatic; $N=22$ ) tions detected in tumour DNA by WES and 109 genes commonly mutated in RCC

\section{INVAR}

Custom-panel targeting 10 genes in renal cancers

INVAR

Chabon et al., 2020 [112]

$C C(N=43,41$ patients with metastatic disease, 35 patients with primary tumour removed)

Stage I-II NSCLC $(N=41)$

Stage III NSCLC $(N=5)$
Tumour-informed search using a 355-kb panel of 255 genes recurrently mutated in NSCLC

Lung-CLiP - a multi-tiered machinelearning approach that includes fragment size to estimate the probability that a ccfDNA mutation is tumour derived
In high ctDNA cancers, an RF model yielded an AUC of 0.994 for distinguishing cancer patients from controls

In low ctDNA cancers, an RF model yielded an AUC of 0.914 for distinguishing cancer patients from controls

An RF model using fragmentation features alone (leaving out tMAD score) yielded AUCs of 0.989 and 0.891 for cancer types with a high and low amount of ctDNA, respectively

ctDNA detected in 11 stage II-III patients (28.9\%, specificity at $98.6 \%)$, and the integrated MAF in 9 of the 11 patients was below the 95\% LOD for a "perfect" single-locus assay based on ccfDNA input amount (AUC $=0.64$ )

ctDNA detected in the baseline samples of 9 stage IV patients (100\%)

ctDNA detected in 50 of 52 treatment and follow-up samples from 9 stage IV patients where the integrated MAF in 15 of the 50 samples was below the 95\% LOD for a "perfect" single-locus assay based on ccfDNA input amount

16 samples from stage I-II breast cancer, sensitivity of $62.5 \%$ at specificity of $90 \%$ (AUC $=0.81$ )

19 samples from stage IV breast cancer, sensitivity of $100 \%$ at specificity of $100 \%$ (AUC $=1.00$ )

8 patients with grade II-IV brain tumours, sensitivity of $75 \%$ at specificity of $90 \%$ (AUC $=0.92$ )

24 patients with stage I-IV renal tumours, sensitivity of $41.7 \%$ at specificity of $90 \%$ (AUC $=0.66$ )

19 patients with stage I-III NSCLC, sensitivity of $63.1 \%$ at specificity of $98 \%$ (AUC $=0.80$ )

ctDNA was detected in 12 patients $(54.5 \%)$

ctDNA was detected in 8 patients (18.6\%)

Mean MAF was $8.3 \%$ (range 3.5-18\%)

For stage I-II patients:

Sensitivity of $\sim 30 \%$ at $98 \%$ specificity

Risk-matched controls $(N=48) \quad$ Sensitivity of $\sim 56 \%$ at $80 \%$ specificity

For stage III patients:

Sensitivity of $\sim 60 \%$ at $98 \%$ specificity

Sensitivity of $\sim 100 \%$ at $80 \%$ specificity

$A U C$ area under the curve, $c c f D N A$ circulating cell-free DNA, $c t D N A$ circulating tumour DNA, INVAR INtegration of VAriant Reads, LOD limit of detection, Lung-CLiP lung cancer likelihood in plasma, $M A F$ mutant allele frequency, $N S C L C$ non-small cell lung cancer, $R C C$ renal cell carcinoma, $R F$ random forest, $s W G S$ shallow whole genome sequencing, $t M A D$ trimmed median absolute deviation from copy number neutrality, WES whole exome sequencing 
patient-specific panels derived from WES of the tumour were generated, which led to new ctDNA detection in 10 of 17 patients (59\%). In a subsequent step, ccfDNA fragment length was integrated into a machine learning algorithm to screen for ctDNA indicative of non-small cell lung cancer in high-risk patients. At $98 \%$ specificity, sensitivity for detecting stage I-II non-small cell lung cancer via ctDNA in 41 patients was $\sim 30 \%$. Collectively, these studies demonstrate the promise of integrating ctDNA fragment length into probability-based models to detect early-stage and difficult to detect cancers. Importantly, there are two key aspects of these studies that merit additional consideration within the context of ccfDNA fragment length. First, ccfDNA fragment length was only one component in the overall ctDNA detection strategy. For example, Chabon et al. used a multi-tiered approach to estimate the probability that a ccfDNA mutation was tumour derived using background frequencies, ccfDNA fragment size, the gene affected, and likelihood of clonal haematopoiesis of indeterminate potential [112]. Second, the studies used fragment length to enhance tumour detection rather than mutation detection. For example, Wan et al. observed in nine of the 11 stage II-III melanoma patients where INVAR detected ctDNA that the integrated MAF determined from multiple loci was below the $95 \%$ limit of detection for a "perfect" single-locus assay based on the ccfDNA input [121], indicating that insufficient read depth and signal were available to confidently determine presence/ absence of each individually targeted mutation in ctDNA. As such, additional studies are needed to determine if machinelearning algorithms using fragment length profiling can be further harnessed to improve detection of individual somatic mutations in ctDNA.

In silico size selection offers a multitude of opportunities to analyse ccfDNA using hard filters, probability modelling, or both. An advantage of in silico size analysis is the integration of fragment length with other features of ccfDNA and/ or other biomarkers of cancer [169] in a lossless manner to optimize ctDNA and tumour detection. Relative to ctDNA enrichment for somatic mutation detection, however, the caveats associated with in silico size selection are identical to those introduced with in vitro enrichment- there is limited data available for MAFs $<1 \%$. Although in silico size selection has been used during detection of foetal ccfDNA in the maternal circulation $[170,171]$, the approaches are similar to that described for ctDNA, and the foetal fraction is generally $>1 \%$, with few exceptions. As such, additional insights are unlikely to be gleaned from reviewing the foetal ccfDNA literature. Accordingly, future studies devoted to using in silico size selection for enrichment of ctDNA associated with early-stage and non-metastatic cancers are needed to better understand the potential impact on mutation-based ctDNA detection to further improve the noninvasive genotyping of tumours.

\section{In Vitro Versus in Silico ccfDNA Size Selection, Which Is Better?}

Both in vitro and in silico approaches to enrich for ctDNA present strengths and challenges. In a direct comparison between methods, Mouliere et al. found that in vitro size selection afforded a higher degree of ctDNA enrichment compared to in silico size selection (mean increase in MAF of 4.19-fold vs. 2.2-fold, respectively) [68]. However, several factors regarding ctDNA fragment size within the context of in vitro size selection warrant careful review. Although ctDNA generally aggregates around a shorter distribution of fragment lengths $(<150 \mathrm{bp})$, longer fragments outside the targeted range for enrichment may also be present. For example, Hellwig et al. found the fraction of isolated ccfDNA fragments with a median length of $167 \mathrm{bp}$ to be associated with a reduced MAF rather than absent ctDNA indicating that ctDNA is not exclusive to fragments $<150 \mathrm{bp}$ [155]. In addition, the size difference between ctDNA and normal ccfDNA has been shown to extend beyond the mononucleosome to the dinucleosome, where a second cluster of enriched ctDNA may occur at 230-310 bp [112, 121, 172]. Finally, Chabon et al. found in silico hard filtering based on ctDNA-enriched size windows disproportionately favoured variants with higher pre-enrichment MAFs [112]. As such, using in vitro size selection to exclude molecules $>150$ bp has the potential to adversely affect sensitivity [173], particularly for ctDNA with a low allele frequency where accrual of DNA losses during sample preparation for NGS may be compounded by the in vitro size-selection process.

Whereas in vitro size selection may lead to irretrievable loss of rare molecules, in silico size selection allows a lossless size-based analysis. In addition, a multitude of size analyses using hard filters and/or probability modelling can be conducted iteratively to optimize ctDNA detection that may be specific to each type and severity of cancer. In combination with bioinformatic strategies to reduce error [174], the additional potential boost in ctDNA signal via in vitro size selection to overcome NGS-associated noise may not be necessary. A potential weakness of in silico size selection is that application of algorithms may lead to fewer samples available for analysis and/or reduced read depth. For example, Smith et al. found that seven of 29 samples (24.1\%) were excluded as technical failures because there were insufficient reads after size selection to meet the requirement of the INVAR algorithm [115]. However, these effects can likely be anticipated and mitigated by using a higher number of total paired reads for each sample during sequencing.

Heretofore, in vitro size selection has been discussed within the context of ctDNA enrichment. However, an in vitro approach may also have beneficial bioinformatic 
effects that merit consideration. Specifically, Hellwig et al. showed that in vitro size selection reduced sample complexity, leading to the generation of larger family sizes without compromising ctDNA detection [155]. During library preparation, amplicons of each unique DNA molecule are generated. Subsequently, molecular barcodes are used to identify amplicons derived from the same original DNA molecule. During in silico analysis of NGS data, amplicons with the same molecular barcode are grouped into a family and used to generate a single consensus sequence that represents the original unique DNA molecule. Family size is the number of amplicons used to generate a consensus sequence and larger family sizes correspond to larger error reduction. Thus, in vitro size selection has the potential to enrich for ctDNA, while concomitantly reducing NGS error.

Currently, there is not strong evidence that supports using one approach over the other. In vitro size selection may enable enrichment of ctDNA while also yielding fewer NGS-associated errors, but at the cost of losing rare ctDNA molecules that may mitigate the desired enrichment effect. In silico size selection allows a multitude of lossless bioinformatic analyses, but at the cost of potentially reduced ctDNA enrichment that may be insufficient to overcome NGS-associated noise. Finally, and perhaps most importantly, there are insufficient data at very low allele frequencies to adequately determine which approach will best position ccfDNA diagnostics to improve non-invasive precision oncology. Until further data become available, study goals will need to continue to dictate integration of in vitro or in silico approaches into experimental designs.

\section{Additional Observations in ctDNA Fragmentation}

Although this review has largely focused on the discrete size difference between ctDNA and ccfDNA relative to the mono- and dinucleosomes, other studies have identified additional size-based differences between ctDNA and ccfDNA that should be considered to provide a more complete overview of ctDNA fragment length. In 2016, single-stranded DNA library preparation methods found that ccfDNA shorter than $100 \mathrm{nt}$ was more accessible compared to the more commonly used double-stranded DNA library generation approach because of the latter's requirement to use size-selective steps to remove adapter dimers, which tends to also eliminate shorter ccfDNA fragments [15, 175]. In 2018, Sanchez et al. used single-stranded DNA library preparation in a small cohort of cancer patients to show highly fragmented ccfDNA with a $10 \mathrm{nt}$ periodicity and a size range of 41 to $167 \mathrm{nt}$. In contrast, double-stranded DNA library preparation yielded the same periodicity, but was observed only from 81 to 166 bp [176]. Subsequently,
Liu et al. used single-stranded library preparation to detect ctDNA present in stage II-III pancreatic ductal adenocarcinoma patients with paired tumour DNA and ccfDNA [177]. In 13 patients, they found evidence of corresponding ctDNA in $\sim 69 \%$ of patients that were either the KRAS p.G12D or p.G12C variants (median allele frequency of $0.12 \%$; range $0.05-0.56 \%$ ). Overall, $\sim 30 \%$ of mutations present in tumour tissue with an MAF $>1 \%$ were present in ccfDNA, which were all associated with common KRAS mutations. However, the proportion of pancreatic patients with detected ctDNA was similar to previous reports [44, 45]. In addition, Moser et al. reported that single-stranded DNA library preparation enriched for smaller DNA fragments, but did not preferentially enrich for ctDNA [178]. As such, more direct comparisons between single- and double-stranded DNA library generation inclusive of different preparation methods for both are necessary to determine if the additional steps involved in single-stranded library generation are warranted.

In contrast to previous studies that have shown ctDNA is shorter than ccfDNA, a report in 2019 found that ctDNA fragment length may include both shorter and longer fragments relative to ccfDNA. Cristiano et al. used whole genome sequencing at $1-2 \times$ coverage in 208 cancer patients and analysed the ratio of small (100-150 bp) to large (151-220 bp) ccfDNA fragments to evaluate the fragmentation profile in 504 windows of $5 \mathrm{Mb}$, covering approximately $2.6 \mathrm{~Gb}$ of the genome [160]. They found the ratio indicated both longer and shorter fractions associated with cancer. Moreover, the size profile indicated tissue of origin. Across a range of stages and cancer types, detection of cancer ranged between 68 and $79 \%$ at a $98 \%$ specificity. The origins of the variation of fragment lengths within the same patient are unclear. The authors hypothesized that the fragmentation pattern in patients with cancer likely resulted from mixtures of nucleosomal DNA from blood and neoplastic cells that reflected both epigenomic and genomic alterations. Although genomic monitoring may not identify patient-specific somatic mutations, broad surveillance of cancer across multiple types of malignancy may be feasible by profiling the fragmentation profile across the entire genome.

Finally, viral genomes appear to have an alternate size profile after integration into somatic cells that may enable viral-driven malignancies to be discerned from an active or concurrent viral infection. Lam et al. studied the size profile of Epstein-Barr virus (EBV) with and without the occurrence of nasopharyngeal carcinoma (NPC) [179]. They observed that EBV DNA in plasma from non-NPC patients were distributed over shorter fragment lengths compared to NPC patients, leading to a higher proportion of EBV DNA molecules shorter than $110 \mathrm{bp}$ in non-NPC patients. Subsequently, the proportion of EBV DNA within 80-110 bp relative to autosomal DNA within $80-110$ bp was used to discern EBV-positive patients at a higher risk of harbouring NPC. 
These observations regarding the viral genome fragmentation pattern may have significant implications for detecting a variety of virus-associated cancers such as human papilloma virus-associated squamous cell carcinoma [180].

\section{Conclusions}

Over the past decade, tremendous growth in the development of ccfDNA as a diagnostic tool in oncology has occurred. Challenges associated with the amount of ccfDNA available in plasma (i.e. signal) and errors associated with NGS (i.e. noise) have driven significant advances in the state of the art. Leveraging differences in fragment size between ctDNA and healthy ccfDNA may be one avenue of innovation that further advances clinical applications in oncology. Both in vitro and in silico data for ctDNA enrichment and detection are encouraging. Overall, however, there is a paucity of data to support definitive conclusions regarding utility in clinical diagnostics, particularly for early-stage and nonmetastatic cancers. Many key questions persist. For example, does in vitro enrichment for ctDNA adversely affect detection of ultra-low-frequency ctDNA because of losses that may occur during sample recovery? Can in silico probability estimates of ctDNA based on fragment size be used to discover patient-specific somatic mutations without a tumour-informed search? Is a combination of in vitro and in silico methods warranted? Future studies that address these questions, among others, would provide the necessary evidence to establish fragment length as a key component in ccfDNA diagnostics. Additionally, greater inclusion of healthy control data into experimental designs may provide better support for determination of assay specificity, especially as ccfDNA diagnostics advances towards harder to detect cancers. Finally, investigations into the mechanisms that govern the size difference between ctDNA and ccfDNA may prove meaningful not only for detection, but also lead to new therapeutic strategies. Regardless, ctDNA's fragmentation pattern is an exploitable biologic phenomenon with the potential to enhance ctDNA detection in clinical oncology that may lead to an advanced era of non-invasive, personalized cancer diagnostics to improve patient outcomes.

Acknowledgements BioRender.com was used for figure generation.

\section{Declarations}

Funding National Cancer Institute of the National Institutes of Health (HRU; R37CA246183).

Conflict of interest The author (HRU) has a US patent pending (US2019106737-A1) for using size selection of cell-free DNA to increase family size during next-generation sequencing.
Ethics approval Not applicable

Author contributions HRU is the sole author and is responsible for all content.

Open Access This article is licensed under a Creative Commons Attribution-NonCommercial 4.0 International License, which permits any non-commercial use, sharing, adaptation, distribution and reproduction in any medium or format, as long as you give appropriate credit to the original author(s) and the source, provide a link to the Creative Commons licence, and indicate if changes were made. The images or other third party material in this article are included in the article's Creative Commons licence, unless indicated otherwise in a credit line to the material. If material is not included in the article's Creative Commons licence and your intended use is not permitted by statutory regulation or exceeds the permitted use, you will need to obtain permission directly from the copyright holder. To view a copy of this licence, visit http://creativecommons.org/licenses/by-nc/4.0/.

\section{References}

1. Mandel P, Métais P. Les acides nucléiques du plasma sanguin chez l'homme. C R Seances Soc Biol Fil. 1948;142(3-4):241-3.

2. Leon SA, Shapiro B, Sklaroff DM, Yaros MJ. Free DNA in the serum of cancer patients and the effect of therapy. Can Res. 1977;37(3):646-50.

3. Diehl F, Li M, Dressman D, He Y, Shen D, Szabo S, et al. Detection and quantification of mutations in the plasma of patients with colorectal tumors. Proc Natl Acad Sci USA. 2005;102(45):16368-73.

4. Sozzi G, Conte D, Leon M, Ciricione R, Roz L, Ratcliffe C, et al. Quantification of free circulating DNA as a diagnostic marker in lung cancer. J Clin Oncol. 2003;21(21):3902-8.

5. Huang ZH, Li LH, Hua D. Quantitative analysis of plasma circulating DNA at diagnosis and during follow-up of breast cancer patients. Cancer Lett. 2006;243(1):64-70.

6. Jylhava J, Kotipelto T, Raitala A, Jylha M, Hervonen A, Hurme $M$. Aging is associated with quantitative and qualitative changes in circulating cell-free DNA: the vitality 90+ study. Mech Ageing Dev. 2011;132(1-2):20-6.

7. Haghiac M, Vora NL, Basu S, Johnson KL, Presley L, Bianchi DW, et al. Increased death of adipose cells, a path to release cell-free DNA into systemic circulation of obese women. Obesity (Silver Spring). 2012;20(11):2213-9.

8. Tan EM, Schur PH, Carr RI, Kunkel HG. Deoxybonucleic acid (DNA) and antibodies to DNA in the serum of patients with systemic lupus erythematosus. J Clin Investig. 1966;45(11):1732-40.

9. Boender PJ, Heijtink RA, Hellings JA. Nucleosomal fragments in serum may directly reflect cell-mediated cytotoxic activity in vivo. Clin Immunol Immunopathol. 1989;53(1):87-98.

10. Stawski R, Walczak K, Kosielski P, Meissner P, Budlewski $\mathrm{T}$, Padula $\mathrm{G}$, et al. Repeated bouts of exhaustive exercise increase circulating cell free nuclear and mitochondrial DNA without development of tolerance in healthy men. PLoS One. 2017;12(5):e0178216.

11. Dawson SJ, Tsui DW, Murtaza M, Biggs H, Rueda OM, Chin SF, et al. Analysis of circulating tumor DNA to monitor metastatic breast cancer. N Engl J Med. 2013;368(13):1199-209.

12. Sorenson GD, Pribish DM, Valone FH, Memoli VA, Bzik DJ, Yao SL. Soluble normal and mutated DNA sequences from single-copy genes in human blood. Cancer Epidemiol Biomark Prev. 1994;3(1):67-71. 
13. Sun K, Jiang P, Chan KC, Wong J, Cheng YK, Liang RH, et al. Plasma DNA tissue mapping by genome-wide methylation sequencing for noninvasive prenatal, cancer, and transplantation assessments. Proc Natl Acad Sci USA. 2015;112(40):E5503-12.

14. Moss J, Magenheim J, Neiman D, Zemmour H, Loyfer N, Korach A, et al. Comprehensive human cell-type methylation atlas reveals origins of circulating cell-free DNA in health and disease. Nat Commun. 2018;9(1):5068.

15. Snyder MW, Kircher M, Hill AJ, Daza RM, Shendure J. Cell-free DNA comprises an in vivo nucleosome footprint that informs its tissues-of-origin. Cell. 2016;164(1-2):57-68.

16. Laurent D, Semple F, Starkey Lewis PJ, Rose E, Black HA, Coe $\mathrm{J}$, et al. Absolute measurement of the tissue origins of cell-free DNA in the healthy state and following paracetamol overdose. BMC Med Genom. 2020;13(1):60.

17. Long-Mira E, Ilie M, Chamorey E, Leduff-Blanc F, Montaudie H, Tanga V, et al. Monitoring BRAF and NRAS mutations with cellfree circulating tumor DNA from metastatic melanoma patients. Oncotarget. 2018;9(90):36238-49.

18. Board RE, Wardley AM, Dixon JM, Armstrong AC, Howell S, Renshaw L, et al. Detection of PIK3CA mutations in circulating free DNA in patients with breast cancer. Breast Cancer Res Treat. 2010;120(2):461-7.

19. Schwarzenbach H, Alix-Panabieres C, Muller I, Letang N, Vendrell JP, Rebillard X, et al. Cell-free tumor DNA in blood plasma as a marker for circulating tumor cells in prostate cancer. Clin Cancer Res. 2009;15(3):1032-8.

20. Taniguchi K, Uchida J, Nishino K, Kumagai T, Okuyama T, Okami J, et al. Quantitative detection of EGFR mutations in circulating tumor DNA derived from lung adenocarcinomas. Clin Cancer Res. 2011;17(24):7808-15.

21. Panka DJ, Sullivan RJ, Mier JW. An inexpensive, specific and highly sensitive protocol to detect the BrafV600E mutation in melanoma tumor biopsies and blood. Melanoma Res. 2010;20(5):401-7.

22. Mulcahy HE, Lyautey J, Lederrey C, Qi CX, Anker P, Alstead $\mathrm{EM}$, et al. A prospective study of K-ras mutations in the plasma of pancreatic cancer patients. Clin Cancer Res. 1998;4(2):271-5.

23. Castells A, Puig P, Mora J, Boadas J, Boix L, Urgell E, et al. K-ras mutations in DNA extracted from the plasma of patients with pancreatic carcinoma: diagnostic utility and prognostic significance. J Clin Oncol. 1999;17(2):578-84.

24. Shinozaki M, O'Day SJ, Kitago M, Amersi F, Kuo C, Kim J, et al. Utility of circulating B-RAF DNA mutation in serum for monitoring melanoma patients receiving biochemotherapy. Clin Cancer Res. 2007;13(7):2068-74.

25. Forshew T, Murtaza M, Parkinson C, Gale D, Tsui DW, Kaper F, et al. Noninvasive identification and monitoring of cancer mutations by targeted deep sequencing of plasma DNA. Sci Transl Med. 2012;4(136):136ra68.

26. Narayan A, Carriero NJ, Gettinger SN, Kluytenaar J, Kozak KR, Yock TI, et al. Ultrasensitive measurement of hotspot mutations in tumor DNA in blood using error-suppressed multiplexed deep sequencing. Can Res. 2012;72(14):3492-8.

27. Bettegowda C, Sausen M, Leary RJ, Kinde I, Wang Y, Agrawal N, et al. Detection of circulating tumor DNA in early- and late-stage human malignancies. Sci Transl Med. 2014;6(224):224ra24.

28. Nix DA, Hellwig S, Conley C, Thomas A, Fuertes CL, Hamil CL, et al. The stochastic nature of errors in next-generation sequencing of circulating cell-free DNA. PLoS One. 2020;15(2): 0229063.

29. Liao W, Yang H, Xu H, Wang Y, Ge P, Ren J, et al. Noninvasive detection of tumor-associated mutations from circulating cellfree DNA in hepatocellular carcinoma patients by targeted deep sequencing. Oncotarget. 2016;7(26):40481-90.
30. Schwaederle M, Husain H, Fanta PT, Piccioni DE, Kesari S, Schwab RB, et al. Detection rate of actionable mutations in diverse cancers using a biopsy-free (blood) circulating tumor cell DNA assay. Oncotarget. 2016;7(9):9707-17.

31. Ueda M, Iguchi T, Masuda T, Nakahara Y, Hirata H, Uchi R, et al. Somatic mutations in plasma cell-free DNA are diagnostic markers for esophageal squamous cell carcinoma recurrence. Oncotarget. 2016;7(38):62280-91.

32. Ohira T, Sakai K, Matsubayashi J, Kajiwara N, Kakihana M, Hagiwara M, et al. Tumor volume determines the feasibility of cell-free DNA sequencing for mutation detection in non-small cell lung cancer. Cancer Sci. 2016;107(11):1660-6.

33. Scherer F, Kurtz DM, Newman AM, Stehr H, Craig AF, Esfahani MS, et al. Distinct biological subtypes and patterns of genome evolution in lymphoma revealed by circulating tumor DNA. Sci Transl Med. 2016;8(364):364ra155.

34. Thompson JC, Yee SS, Troxel AB, Savitch SL, Fan R, Balli D, et al. Detection of therapeutically targetable driver and resistance mutations in lung cancer patients by next-generation sequencing of cell-free circulating tumor DNA. Clin Cancer Res. 2016;22(23):5772-82.

35. Liang DH, Ensor JE, Liu ZB, Patel A, Patel TA, Chang JC, et al. Cell-free DNA as a molecular tool for monitoring disease progression and response to therapy in breast cancer patients. Breast Cancer Res Treat. 2016;155(1):139-49.

36. Rachiglio AM, Esposito Abate R, Sacco A, Pasquale R, Fenizia $\mathrm{F}$, Lambiase $\mathrm{M}$, et al. Limits and potential of targeted sequencing analysis of liquid biopsy in patients with lung and colon carcinoma. Oncotarget. 2016;7(41):66595-605.

37. Newman AM, Lovejoy AF, Klass DM, Kurtz DM, Chabon JJ, Scherer F, et al. Integrated digital error suppression for improved detection of circulating tumor DNA. Nat Biotechnol. 2016;34(5):547-55.

38. Chae YK, Davis AA, Carneiro BA, Chandra S, Mohindra N, Kalyan A, et al. Concordance between genomic alterations assessed by next-generation sequencing in tumor tissue or circulating cell-free DNA. Oncotarget. 2016;7(40):65364-73.

39. Jovelet C, Ileana E, Le Deley MC, Motte N, Rosellini S, Romero A, et al. Circulating cell-free tumor DNA analysis of 50 genes by next-generation sequencing in the prospective MOSCATO trial. Clin Cancer Res. 2016;22(12):2960-8.

40. Pishvaian MJ, Joseph Bender R, Matrisian LM, Rahib L, Hendifar A, Hoos WA, et al. A pilot study evaluating concordance between blood-based and patient-matched tumor molecular testing within pancreatic cancer patients participating in the Know Your Tumor (KYT) initiative. Oncotarget. 2017;8(48):83446-56.

41. Wyatt AW, Azad AA, Volik SV, Annala M, Beja K, McConeghy $\mathrm{B}$, et al. Genomic alterations in cell-free DNA and enzalutamide resistance in castration-resistant prostate cancer. JAMA Oncol. 2016;2(12):1598-606.

42. Beije N, Helmijr JC, Weerts MJA, Beaufort CM, Wiggin M, Marziali $\mathrm{A}$, et al. Somatic mutation detection using various targeted detection assays in paired samples of circulating tumor DNA, primary tumor and metastases from patients undergoing resection of colorectal liver metastases. Mol Oncol. 2016;10(10):1575-84.

43. Phallen J, Sausen M, Adleff V, Leal A, Hruban C, White J, et al. Direct detection of early-stage cancers using circulating tumor DNA. Sci Transl Med. 2017;9(403):eaan2415.

44. Cohen JD, Javed AA, Thoburn C, Wong F, Tie J, Gibbs P, et al. Combined circulating tumor DNA and protein biomarker-based liquid biopsy for the earlier detection of pancreatic cancers. Proc Natl Acad Sci USA. 2017;114(38):10202-7.

45. Vietsch EE, Graham GT, McCutcheon JN, Javaid A, Giaccone G, Marshall JL, et al. Circulating cell-free DNA mutation patterns in early and late stage colon and pancreatic cancer. Cancer Genet. 2017;218-219:39-50. 
46. Iwama E, Sakai K, Azuma K, Harada T, Harada D, Nosaki K, et al. Monitoring of somatic mutations in circulating cell-free DNA by digital PCR and next-generation sequencing during afatinib treatment in patients with lung adenocarcinoma positive for EGFR activating mutations. Ann Oncol. 2017;28(1):136-41.

47. Yao Y, Liu J, Li L, Yuan Y, Nan K, Wu X, et al. Detection of circulating tumor DNA in patients with advanced non-small cell lung cancer. Oncotarget. 2017;8(2):2130-40.

48. Mao X, Zhang Z, Zheng X, Xie F, Duan F, Jiang L, et al. Capture-based targeted ultradeep sequencing in paired tissue and plasma samples demonstrates differential subclonal ctDNAreleasing capability in advanced lung cancer. J Thorac Oncol. 2017;12(4):663-72.

49. Janku F, Zhang S, Waters J, Liu L, Huang HJ, Subbiah V, et al. Development and validation of an ultradeep nextgeneration sequencing assay for testing of plasma cell-free DNA from patients with advanced cancer. Clin Cancer Res. 2017;23(18):5648-56.

50. Bartels S, Persing S, Hasemeier B, Schipper E, Kreipe H, Lehmann U. Molecular analysis of circulating cell-free DNA from lung cancer patients in routine laboratory practice: a crossplatform comparison of three different molecular methods for mutation detection. J Mol Diagn. 2017;19(5):722-32.

51. Sandulache VC, Williams MD, Lai SY, Lu C, William WN, Busaidy NL, et al. Real-time genomic characterization utilizing circulating cell-free DNA in patients with anaplastic thyroid carcinoma. Thyroid. 2017;27(1):81-7.

52. Maxwell KN, Soucier-Ernst D, Tahirovic E, Troxel AB, Clark C, Feldman M, et al. Comparative clinical utility of tumor genomic testing and cell-free DNA in metastatic breast cancer. Breast Cancer Res Treat. 2017;164(3):627-38.

53. Adalsteinsson VA, Ha G, Freeman SS, Choudhury AD, Stover DG, Parsons HA, et al. Scalable whole-exome sequencing of cell-free DNA reveals high concordance with metastatic tumors. Nat Commun. 2017;8(1):1324.

54. Wyatt AW, Annala M, Aggarwal R, Beja K, Feng F, Youngren $\mathrm{J}$, et al. Concordance of circulating tumor DNA and matched metastatic tissue biopsy in prostate cancer. J Natl Cancer Inst. 2017;109(12):djx118.

55. Page K, Guttery DS, Fernandez-Garcia D, Hills A, Hastings RK, Luo J, et al. Next generation sequencing of circulating cell-free DNA for evaluating mutations and gene amplification in metastatic breast cancer. Clin Chem. 2017;63(2):532-41.

56. Goldstein A, Toro PV, Lee J, Silberstein JL, Nakazawa M, Waters I, et al. Detection fidelity of AR mutations in plasma derived cell-free DNA. Oncotarget. 2017;8(9):15651-62.

57. Pereira AAL, Morelli MP, Overman M, Kee B, Fogelman D, Vilar E, et al. Clinical utility of circulating cell-free DNA in advanced colorectal cancer. PLoS One. 2017;12(8):e0183949.

58. Koeppel F, Blanchard S, Jovelet C, Genin B, Marcaillou C, Martin $\mathrm{E}$, et al. Whole exome sequencing for determination of tumor mutation load in liquid biopsy from advanced cancer patients. PLoS One. 2017;12(11):e0188174.

59. Kim ST, Banks KC, Lee SH, Kim K, Park JO, Park SH, et al. Prospective feasibility study for using cell-free circulating tumor DNA-guided therapy in refractory metastatic solid cancers: an interim analysis. JCO Precis Oncol. 2017;1:1-15.

60. Guo Q, Wang J, Xiao J, Wang L, Hu X, Yu W, et al. Heterogeneous mutation pattern in tumor tissue and circulating tumor DNA warrants parallel NGS panel testing. Mol Cancer. 2018;17(1):131.

61. Chicard M, Colmet-Daage L, Clement N, Danzon A, Bohec $\mathrm{M}$, Bernard V, et al. Whole-exome sequencing of cell-free DNA reveals temporo-spatial heterogeneity and identifies treatment-resistant clones in neuroblastoma. Clin Cancer Res. 2018;24(4):939-49.
62. Kurtz DM, Scherer F, Jin MC, Soo J, Craig AFM, Esfahani MS, et al. Circulating tumor DNA measurements as early outcome predictors in diffuse large B-cell lymphoma. J Clin Oncol. 2018;36(28):2845-53.

63. Ng CKY, Di Costanzo GG, Tosti N, Paradiso V, Coto-Llerena M, Roscigno G, et al. Genetic profiling using plasma-derived cellfree DNA in therapy-naive hepatocellular carcinoma patients: a pilot study. Ann Oncol. 2018;29(5):1286-91.

64. Veldore VH, Choughule A, Routhu T, Mandloi N, Noronha V, Joshi A, et al. Validation of liquid biopsy: plasma cell-free DNA testing in clinical management of advanced non-small cell lung cancer. Lung Cancer (Auckl). 2018;9:1-11.

65. Guibert N, Hu Y, Feeney N, Kuang Y, Plagnol V, Jones G, et al. Amplicon-based next-generation sequencing of plasma cell-free DNA for detection of driver and resistance mutations in advanced non-small cell lung cancer. Ann Oncol. 2018;29(4):1049-55.

66. Helman E, Nguyen M, Karlovich CA, Despain D, Choquette AK, Spira AI, et al. Cell-free DNA next-generation sequencing prediction of response and resistance to third-generation EGFR inhibitor. Clin Lung Cancer. 2018;19(6):518-30 (e7).

67. Pasternack H, Fassunke J, Plum PS, Chon SH, Hescheler DA, Gassa A, et al. Somatic alterations in circulating cell-free DNA of oesophageal carcinoma patients during primary staging are indicative for post-surgical tumour recurrence. Sci Rep. 2018;8(1):14941.

68. Mouliere F, Chandrananda D, Piskorz AM, Moore EK, Morris J, Ahlborn LB, et al. Enhanced detection of circulating tumor DNA by fragment size analysis. Sci Transl Med. 2018;10(466):eaat4921.

69. Tsui DWY, Murtaza M, Wong ASC, Rueda OM, Smith CG, Chandrananda D, et al. Dynamics of multiple resistance mechanisms in plasma DNA during EGFR-targeted therapies in nonsmall cell lung cancer. EMBO Mol Med. 2018;10(6):e7945.

70. Liu L, Liu H, Shao D, Liu Z, Wang J, Deng Q, et al. Development and clinical validation of a circulating tumor DNA test for the identification of clinically actionable mutations in nonsmall cell lung cancer. Genes Chromosomes Cancer. 2018;57(4):211-20.

71. Gangadhar TC, Savitch SL, Yee SS, Xu W, Huang AC, Harmon $S$, et al. Feasibility of monitoring advanced melanoma patients using cell-free DNA from plasma. Pigment Cell Melanoma Res. 2018;31(1):73-81.

72. Laufer-Geva S, Rozenblum AB, Twito T, Grinberg R, Dvir A, Soussan-Gutman L, et al. The clinical impact of comprehensive genomic testing of circulating cell-free DNA in advanced lung cancer. J Thorac Oncol. 2018;13(11):1705-16.

73. Strickler JH, Loree JM, Ahronian LG, Parikh AR, Niedzwiecki D, Pereira AAL, et al. Genomic landscape of cellfree DNA in patients with colorectal cancer. Cancer Discov. 2018;8(2):164-73.

74. Zill OA, Banks KC, Fairclough SR, Mortimer SA, Vowles JV, Mokhtari R, et al. The Landscape Of Actionable Genomic Alterations In Cell-Free Circulating Tumor DNA from 21,807 advanced cancer patients. Clin Cancer Res. 2018;24(15):3528-38.

75. Perets R, Greenberg O, Shentzer T, Semenisty V, Epelbaum $\mathrm{R}$, Bick T, et al. Mutant KRAS circulating tumor DNA is an accurate tool for pancreatic cancer monitoring. Oncologist. 2018;23(5):566-72.

76. Masunaga N, Kagara N, Motooka D, Nakamura S, Miyake T, Tanei T, et al. Highly sensitive detection of ESR1 mutations in cell-free DNA from patients with metastatic breast cancer using molecular barcode sequencing. Breast Cancer Res Treat. 2018;167(1):49-58

77. Goldberg SB, Narayan A, Kole AJ, Decker RH, Teysir J, Carriero NJ, et al. Early assessment of lung cancer immunotherapy response via circulating tumor DNA. Clin Cancer Res. 2018;24(8):1872-80. 
78. Belic J, Graf R, Bauernhofer T, Cherkas Y, Ulz P, WaldispuehlGeigl J, et al. Genomic alterations in plasma DNA from patients with metastasized prostate cancer receiving abiraterone or enzalutamide. Int J Cancer. 2018;143(5):1236-48.

79. Annala M, Vandekerkhove G, Khalaf D, Taavitsainen S, Beja K, Warner EW, et al. Circulating tumor DNA genomics correlate with resistance to abiraterone and enzalutamide in prostate cancer. Cancer Discov. 2018;8(4):444-57.

80. Lupini L, Moretti A, Bassi C, Schirone A, Pedriali M, Querzoli $\mathrm{P}$, et al. High-sensitivity assay for monitoring ESR1 mutations in circulating cell-free DNA of breast cancer patients receiving endocrine therapy. Sci Rep. 2018;8(1):4371.

81. Mansukhani S, Barber LJ, Kleftogiannis D, Moorcraft SY, Davidson M, Woolston A, et al. Ultra-sensitive mutation detection and genome-wide DNA copy number reconstruction by error-corrected circulating tumor DNA sequencing. Clin Chem. 2018;64(11):1626-35.

82. Xiong Y, Xie CR, Zhang S, Chen J, Yin ZY. Detection of a novel panel of somatic mutations in plasma cell-free DNA and its diagnostic value in hepatocellular carcinoma. Cancer Manag Res. 2019;11:5745-56.

83. Reinert T, Henriksen TV, Christensen E, Sharma S, Salari R, Sethi H, et al. Analysis of plasma cell-free DNA by ultradeep sequencing in patients with stages I to III colorectal cancer. JAMA Oncol. 2019;5(8):1124-31.

84. Peng M, Xie Y, Li X, Qian Y, Tu X, Yao X, et al. Resectable lung lesions malignancy assessment and cancer detection by ultradeep sequencing of targeted gene mutations in plasma cell-free DNA. J Med Genet. 2019;56(10):647-53.

85. Sun P, Chen C, Xia Y, Wang Y, Liu PP, Bi XW, et al. Mutation profiling of malignant lymphoma by next-generation sequencing of circulating cell-free DNA. J Cancer. 2019;10(2):323-31.

86. Meng P, Wei J, Geng Y, Chen S, Terpstra MM, Huang Q, et al. Targeted sequencing of circulating cell-free DNA in stage II-III resectable oesophageal squamous cell carcinoma patients. BMC Cancer. 2019;19(1):818

87. Mohan S, Ayub M, Rothwell DG, Gulati S, Kilerci B, Hollebecque A, et al. Analysis of circulating cell-free DNA identifies KRAS copy number gain and mutation as a novel prognostic marker in pancreatic cancer. Sci Rep. 2019;9(1):11610.

88. Zhang Y, Chang L, Yang Y, Fang W, Guan Y, Wu A, et al. Intratumor heterogeneity comparison among different subtypes of non-small-cell lung cancer through multi-region tissue and matched ctDNA sequencing. Mol Cancer. 2019;18(1):7.

89. Takeda K, Yamada T, Takahashi G, Iwai T, Ueda K, Kuriyama $\mathrm{S}$, et al. Analysis of colorectal cancer-related mutations by liquid biopsy: Utility of circulating cell-free DNA and circulating tumor cells. Cancer Sci. 2019;110(11):3497-509.

90. Zhang B, Niu X, Zhang Q, Wang C, Liu B, Yue D, et al. Circulating tumor DNA detection is correlated to histologic types in patients with early-stage non-small-cell lung cancer. Lung Cancer. 2019;134:108-16.

91. Chen Y, Han T, Zhou Y, Mao B, Zhuang W. Comparing the efficacy of targeted next-generation sequencing in the identification of somatic mutations in circulating tumor DNA from different stages of lung cancer. Neoplasma. 2019;66(4):652-60.

92. An Y, Guan Y, Xu Y, Han Y, Wu C, Bao C, et al. The diagnostic and prognostic usage of circulating tumor DNA in operable hepatocellular carcinoma. Am J Transl Res. 2019;11(10):6462-74.

93. Howell J, Atkinson SR, Pinato DJ, Knapp S, Ward C, Minisini R, et al. Identification of mutations in circulating cell-free tumour DNA as a biomarker in hepatocellular carcinoma. Eur J Cancer. 2019;116:56-66.

94. Guibert N, Jones G, Beeler JF, Plagnol V, Morris C, Mourlanette $\mathrm{J}$, et al. Targeted sequencing of plasma cell-free DNA to predict response to PD1 inhibitors in advanced non-small cell lung cancer. Lung Cancer. 2019;137:1-6.

95. Shi X, Duose DY, Mehrotra M, Harmon MA, Hu P, Wistuba II, et al. Non-invasive genotyping of metastatic colorectal cancer using circulating cell free DNA. Cancer Genet. 2019;237:82-9.

96. Wei T, Zhang Q, Li X, Su W, Li G, Ma T, et al. Monitoring tumor burden in response to FOLFIRINOX chemotherapy via profiling circulating cell-free DNA in pancreatic cancer. Mol Cancer Ther. 2019;18(1):196-203.

97. Yamamoto Y, Uemura M, Fujita M, Maejima K, Koh Y, Matsushita $\mathrm{M}$, et al. Clinical significance of the mutational landscape and fragmentation of circulating tumor DNA in renal cell carcinoma. Cancer Sci. 2019;110(2):617-28.

98. Zugazagoitia J, Ramos I, Trigo JM, Palka M, Gomez-Rueda A, Jantus-Lewintre E, et al. Clinical utility of plasma-based digital next-generation sequencing in patients with advance-stage lung adenocarcinomas with insufficient tumor samples for tissue genotyping. Ann Oncol. 2019;30(2):290-6.

99. Kaseb AO, Sanchez NS, Sen S, Kelley RK, Tan B, Bocobo AG, et al. Molecular profiling of hepatocellular carcinoma using circulating cell-free DNA. Clin Cancer Res. 2019;25(20):6107-18.

100. Sanchez NS, Kahle MP, Bailey AM, Wathoo C, Balaji K, Demirhan ME, et al. Identification of actionable genomic alterations using circulating cell-free DNA. JCO Precis Oncol. 2019;3:1-10.

101. Osumi H, Shinozaki E, Takeda Y, Wakatsuki T, Ichimura T, Saiura A, et al. Clinical relevance of circulating tumor DNA assessed through deep sequencing in patients with metastatic colorectal cancer. Cancer Med. 2019;8(1):408-17.

102. Sonpavde G, Agarwal N, Pond GR, Nagy RJ, Nussenzveig RH, Hahn AW, et al. Circulating tumor DNA alterations in patients with metastatic castration-resistant prostate cancer. Cancer. 2019;125(9):1459-69.

103. Keup C, Storbeck M, Hauch S, Hahn P, Sprenger-Haussels M, Tewes M, et al. Cell-free DNA variant sequencing using CTCdepleted blood for comprehensive liquid biopsy testing in metastatic breast cancer. Cancers (Basel). 2019;11(2):238.

104. Li S, Wang X, Li Y, Lai H, Liu Y, Jin L. Non-invasive analysis of tumor mutation profiles and druggable mutations by sequencing of cell free DNA of Chinese metastatic breast cancer patients. Thorac Cancer. 2019;10(4):807-14.

105. Li BT, Janku F, Jung B, Hou C, Madwani K, Alden R, et al. Ultra-deep next-generation sequencing of plasma cell-free DNA in patients with advanced lung cancers: results from the Actionable Genome Consortium. Ann Oncol. 2019;30(4):597-603.

106. Torquato S, Pallavajjala A, Goldstein A, Toro PV, Silberstein $\mathrm{JL}$, Lee J, et al. Genetic alterations detected in cell-free DNA are associated with enzalutamide and abiraterone resistance in castration-resistant prostate cancer. JCO Precis Oncol. 2019;3:1-14.

107. van Helden EJ, Angus L, van der Houven M, van Oordt CW, Heideman DAM, Boon E, van Es SC, et al. RAS and BRAF mutations in cell-free DNA are predictive for outcome of cetuximab monotherapy in patients with tissue-tested RAS wild-type advanced colorectal cancer. Mol Oncol. 2019;13(11):2361-74.

108. Taavitsainen S, Annala M, Ledet E, Beja K, Miller PJ, Moses M, et al. Evaluation of commercial circulating tumor DNA test in metastatic prostate cancer. JCO Precis Oncol. 2019;3:1-9.

109. Jiang J, Adams HP, Yao L, Yaung S, Lal P, Balasubramanyam A, et al. Concordance of genomic alterations by next-generation sequencing in tumor tissue versus cell-free DNA in stage I-IV non-small cell lung cancer. J Mol Diagn. 2020;22(2):228-35.

110. Ottestad AL, Wahl SGF, Gronberg BH, Skorpen F, Dai HY. The relevance of tumor mutation profiling in interpretation of NGS data from cell-free DNA in non-small cell lung cancer patients. Exp Mol Pathol. 2020;112:104347. 
111. Serrano C, Vivancos A, Lopez-Pousa A, Matito J, Mancuso FM, Valverde $\mathrm{C}$, et al. Clinical value of next generation sequencing of plasma cell-free DNA in gastrointestinal stromal tumors. BMC Cancer. 2020;20(1):99.

112. Chabon JJ, Hamilton EG, Kurtz DM, Esfahani MS, Moding EJ, $\mathrm{Stehr} \mathrm{H}$, et al. Integrating genomic features for non-invasive early lung cancer detection. Nature. 2020;580(7802):245-51.

113. Radovich M, Jiang G, Hancock BA, Chitambar C, Nanda R, Falkson C, et al. Association of circulating tumor DNA and circulating tumor cells after neoadjuvant chemotherapy with disease recurrence in patients with triple-negative breast cancer: preplanned secondary analysis of the BRE12-158 randomized clinical trial. JAMA Oncol. 2020;6(9):1410-5.

114. Ohara S, Suda K, Sakai K, Nishino M, Chiba M, Shimoji M, et al. Prognostic implications of preoperative versus postoperative circulating tumor DNA in surgically resected lung cancer patients: a pilot study. Transl Lung Cancer Res. 2020;9(5):1915-23.

115. Smith CG, Moser T, Mouliere F, Field-Rayner J, Eldridge M, Riediger AL, et al. Comprehensive characterization of cell-free tumor DNA in plasma and urine of patients with renal tumors. Genome Med. 2020;12(1):23.

116. Ishida Y, Takano S, Maekawa S, Yamaguchi T, Yoshida T, Kobayashi S, et al. Fractionated small cell-free DNA increases possibility to detect cancer-related gene mutations in advanced colorectal cancer. JGH Open. 2020;4(5):978-86.

117. Openshaw MR, Mohamed AA, Ottolini B, Fernandez-Garcia D, Richards CJ, Page K, et al. Longitudinal monitoring of circulating tumour DNA improves prognostication and relapse detection in gastroesophageal adenocarcinoma. $\mathrm{Br} \mathrm{J}$ Cancer. 2020;123(8):1271-9.

118. Lan X, Bao H, Ge X, Cao J, Fan X, Zhang Q, et al. Genomic landscape of metastatic papillary thyroid carcinoma and novel biomarkers for predicting distant metastasis. Cancer Sci. 2020;111(6):2163-73.

119. Zviran A, Schulman RC, Shah M, Hill STK, Deochand S, Khamnei CC, et al. Genome-wide cell-free DNA mutational integration enables ultra-sensitive cancer monitoring. Nat Med. 2020;26(7):1114-24.

120. Zhao W, Qiu L, Liu H, Xu Y, Zhan M, Zhang W, et al. Circulating tumor DNA as a potential prognostic and predictive biomarker during interventional therapy of unresectable primary liver cancer. J Gastrointest Oncol. 2020;11(5):1065-77.

121. Wan JCM, Heider K, Gale D, Murphy S, Fisher E, Mouliere $\mathrm{F}$, et al. ctDNA monitoring using patient-specific sequencing and integration of variant reads. Sci Transl Med. 2020;12(548):eaaz8084.

122. Macgregor-Das A, Yu J, Tamura K, Abe T, Suenaga M, Shindo $\mathrm{K}$, et al. Detection of circulating tumor DNA in patients with pancreatic cancer using digital next-generation sequencing. J Mol Diagn. 2020;22(6):748-56.

123. Xu B, Shan G, Wu Q, Li W, Wang H, Li H, et al. Concordance of genomic alterations between circulating tumor DNA and matched tumor tissue in Chinese patients with breast cancer. J Oncol. 2020;2020:4259293.

124. Leal A, van Grieken NCT, Palsgrove DN, Phallen J, Medina JE, Hruban C, et al. White blood cell and cell-free DNA analyses for detection of residual disease in gastric cancer. Nat Commun. 2020;11(1):525.

125. Kleftogiannis D, Ho D, Liew JX, Poon PSY, Gan A, Ng RC, et al. Detection of genomic alterations in breast cancer with circulating tumour DNA sequencing. Sci Rep. 2020;10(1):16774.

126. Iwama E, Sakai K, Hidaka N, Inoue K, Fujii A, Nakagaki N, et al. Longitudinal monitoring of somatic genetic alterations in circulating cell-free DNA during treatment with epidermal growth factor receptor-tyrosine kinase inhibitors. Cancer. 2020;126(1):219-27.
127. Fukuhara T, Saito H, Furuya N, Watanabe K, Sugawara S, Iwasawa $\mathrm{S}$, et al. Evaluation of plasma EGFR mutation as an early predictor of response of erlotinib plus bevacizumab treatment in the NEJ026 study. EBioMedicine. 2020;57:102861.

128. Winn JS, Hasse Z, Slifker M, Pei J, Arisi-Fernandez SM, Talarchek JN, et al. Genetic variants detected using cell-free DNA from blood and tumor samples in patients with inflammatory breast cancer. Int J Mol Sci. 2020;21(4):1290.

129. Razavi P, Li BT, Brown DN, Jung B, Hubbell E, Shen R, et al. High-intensity sequencing reveals the sources of plasma circulating cell-free DNA variants. Nat Med. 2019;25(12):1928-37.

130. Liu HE, Vuppalapaty M, Wilkerson C, Renier C, Chiu M, Lemaire $\mathrm{C}$, et al. Detection of EGFR mutations in cfDNA and CTCs, and comparison to tumor tissue in non-small-cell-lungcancer (NSCLC) patients. Front Oncol. 2020;10:572895.

131. Bagley SJ, Nabavizadeh SA, Mays JJ, Till JE, Ware JB, Levy S, et al. Clinical utility of plasma cell-free DNA in adult patients with newly diagnosed glioblastoma: a pilot prospective study. Clin Cancer Res. 2020;26(2):397-407.

132. He Y, Ma X, Chen K, Liu F, Cai S, Han-Zhang H, et al. Perioperative circulating tumor DNA in colorectal liver metastases: concordance with metastatic tissue and predictive value for tumor burden and prognosis. Cancer Manag Res. 2020;12:1621-30.

133. Bustamante Alvarez JG, Janse S, Owen DH, Kiourtsis S, Bertino $\mathrm{EM}, \mathrm{He} \mathrm{K}$, et al. Treatment of non-small-cell lung cancer based on circulating cell-free DNA and impact of variation allele frequency. Clin Lung Cancer. 2020. https://doi.org/10.1016/j.cllc. 2020.11.007.

134. Palmieri M, Baldassarri M, Fava F, Fabbiani A, Gelli E, Tita R, et al. Two-point-NGS analysis of cancer genes in cell-free DNA of metastatic cancer patients. Cancer Med. 2020;9(6):2052-61.

135. Pairawan S, Hess KR, Janku F, Sanchez NS, Mills Shaw KR, Eng $\mathrm{C}$, et al. Cell-free circulating tumor DNA variant allele frequency associates with survival in metastatic cancer. Clin Cancer Res. 2020;26(8):1924-31.

136. Shibayama T, Low SK, Ono M, Kobayashi T, Kobayashi K, Fukada I, et al. Clinical significance of gene mutation in ctDNA analysis for hormone receptor-positive metastatic breast cancer. Breast Cancer Res Treat. 2020;180(2):331-41.

137. Davis AA, Jacob S, Gerratana L, Shah AN, Wehbe F, Katam N, et al. Landscape of circulating tumour DNA in metastatic breast cancer. EBioMedicine. 2020;58:102914.

138. Keup C, Benyaa K, Hauch S, Sprenger-Haussels M, Tewes M, Mach $\mathrm{P}$, et al. Targeted deep sequencing revealed variants in cellfree DNA of hormone receptor-positive metastatic breast cancer patients. Cell Mol Life Sci. 2020;77(3):497-509.

139. Gupta R, Othman T, Chen C, Sandhu J, Ouyang C, Fakih M. Guardant360 circulating tumor DNA assay is concordant with FoundationOne next-generation sequencing in detecting actionable driver mutations in anti-EGFR Naive metastatic colorectal cancer. Oncologist. 2020;25(3):235-43.

140. Kohli M, Tan W, Zheng T, Wang A, Montesinos C, Wong C, et al. Clinical and genomic insights into circulating tumor DNAbased alterations across the spectrum of metastatic hormonesensitive and castrate-resistant prostate cancer. EBioMedicine. 2020;54:102728.

141. Keup C, Storbeck M, Hauch S, Hahn P, Sprenger-Haussels M, Hoffmann O, et al. Multimodal targeted deep sequencing of circulating tumor cells and matched cell-free DNA provides a more comprehensive tool to identify therapeutic targets in metastatic breast cancer patients. Cancers (Basel). 2020;12(5):1084.

142. Dietz S, Christopoulos P, Yuan Z, Angeles AK, Gu L, Volckmar $\mathrm{AL}$, et al. Longitudinal therapy monitoring of ALK-positive lung cancer by combined copy number and targeted mutation profiling of cell-free DNA. EBioMedicine. 2020;62:103103. 
143. Newman AM, Lovejoy AF, Klass DM, Kurtz DM, Chabon JJ, Scherer F, et al. Integrated digital error suppression for improved detection of circulating tumor DNA. Nat Biotechnol. 2016;34(5):547-55.

144. Jiang P, Lo YM. The long and short of circulating cell-free DNA and the ins and outs of molecular diagnostics. Trends Genet. 2016;32(6):360-71.

145. Jahr S, Hentze H, Englisch S, Hardt D, Fackelmayer FO, Hesch $\mathrm{RD}$, et al. DNA fragments in the blood plasma of cancer patients: quantitations and evidence for their origin from apoptotic and necrotic cells. Can Res. 2001;61(4):1659-65.

146. Thierry AR, Mouliere F, Gongora C, Ollier J, Robert B, Ychou $\mathrm{M}$, et al. Origin and quantification of circulating DNA in mice with human colorectal cancer xenografts. Nucleic Acids Res. 2010;38(18):6159-75.

147. Mouliere F, Robert B, Arnau Peyrotte E, Del Rio M, Ychou M, Molina F, et al. High fragmentation characterizes tumour-derived circulating DNA. PLoS One. 2011;6(9):e23418.

148. Ellinger J, Bastian PJ, Ellinger N, Kahl P, Perabo FG, Buttner $\mathrm{R}$, et al. Apoptotic DNA fragments in serum of patients with muscle invasive bladder cancer: a prognostic entity. Cancer Lett. 2008;264(2):274-80.

149. Jiang $\mathrm{P}$, Chan $\mathrm{CW}$, Chan KC, Cheng SH, Wong J, Wong $\mathrm{VW}$, et al. Lengthening and shortening of plasma DNA in hepatocellular carcinoma patients. Proc Natl Acad Sci USA. 2015;112(11):E1317-25.

150. Underhill HR, Kitzman JO, Hellwig S, Welker NC, Daza R, Baker DN, et al. Fragment length of circulating tumor DNA. PLoS Genet. 2016;12(7):e1006162.

151. Giacona MB, Ruben GC, Iczkowski KA, Roos TB, Porter DM, Sorenson GD. Cell-free DNA in human blood plasma: length measurements in patients with pancreatic cancer and healthy controls. Pancreas. 1998;17(1):89-97.

152. Lo YM, Chan KC, Sun H, Chen EZ, Jiang P, Lun FM, et al. Maternal plasma DNA sequencing reveals the genome-wide genetic and mutational profile of the fetus. Sci Transl Med. 2010;2(61):61ra91.

153. Zheng YW, Chan KC, Sun H, Jiang P, Su X, Chen EZ, et al. Nonhematopoietically derived DNA is shorter than hematopoietically derived DNA in plasma: a transplantation model. Clin Chem. 2012;58(3):549-58.

154. Lapin M, Oltedal S, Tjensvoll K, Buhl T, Smaaland R, Garresori $\mathrm{H}$, et al. Fragment size and level of cell-free DNA provide prognostic information in patients with advanced pancreatic cancer. J Transl Med. 2018;16(1):300.

155. Hellwig S, Nix DA, Gligorich KM, O'Shea JM, Thomas A, Fuertes CL, et al. Automated size selection for short cellfree DNA fragments enriches for circulating tumor DNA and improves error correction during next generation sequencing. PLoS One. 2018;13(7):e0197333.

156. Shi J, Zhang R, Li J, Zhang R. Size profile of cell-free DNA: a beacon guiding the practice and innovation of clinical testing. Theranostics. 2020;10(11):4737-48.

157. Cheng THT, Lui KO, Peng XL, Cheng SH, Jiang P, Chan KCA, et al. DNase1 does not appear to play a major role in the fragmentation of plasma DNA in a knockout mouse model. Clin Chem. 2018;64(2):406-8.

158. Han DSC, Ni M, Chan RWY, Chan VWH, Lui KO, Chiu RWK, et al. The biology of cell-free DNA fragmentation and the roles of DNASE1, DNASE1L3, and DFFB. Am J Hum Genet. 2020;106(2):202-14.

159. Guo J, Ma K, Bao H, Ma X, Xu Y, Wu X, et al. Quantitative characterization of tumor cell-free DNA shortening. BMC Genom. 2020;21(1):473.
160. Cristiano S, Leal A, Phallen J, Fiksel J, Adleff V, Bruhm DC, et al. Genome-wide cell-free DNA fragmentation in patients with cancer. Nature. 2019;570(7761):385-9.

161. Ivanov M, Baranova A, Butler T, Spellman P, Mileyko V. Nonrandom fragmentation patterns in circulating cell-free DNA reflect epigenetic regulation. BMC Genom. 2015;16(Suppl 13):S1

162. van der Pol Y, Mouliere F. Toward the early detection of cancer by decoding the epigenetic and environmental fingerprints of cell-free DNA. Cancer Cell. 2019;36(4):350-68.

163. Hahn T, Drese KS, O'Sullivan CK. Microsystem for isolation of fetal DNA from maternal plasma by preparative size separation. Clin Chem. 2009;55(12):2144-52.

164. Yang Q, Du Z, Song Y, Gao S, Yu S, Zhu H, et al. Size-selective separation and overall-amplification of cell-free fetal DNA fragments using PCR-based enrichment. Sci Rep. 2017;19(7):40936.

165. DeAngelis MM, Wang DG, Hawkins TL. Solid-phase reversible immobilization for the isolation of PCR products. Nucleic Acids Res. 1995;23(22):4742-3.

166. Hu P, Liang D, Chen Y, Lin Y, Qiao F, Li H, et al. An enrichment method to increase cell-free fetal DNA fraction and significantly reduce false negatives and test failures for non-invasive prenatal screening: a feasibility study. J Transl Med. 2019;17(1):124.

167. Welker NC, Lee AK, Kjolby RAS, Wan HY, Theilmann MR, Jeon D, et al. High-throughput fetal fraction amplification increases analytical performance of noninvasive prenatal screening. Genet Med. 2021;23(3):443-50.

168. Nygard L, Ahlborn LB, Persson GF, Chandrananda D, Langer JW, Fischer BM, et al. Circulating cell free DNA during definitive chemo-radiotherapy in non-small cell lung cancer patientsinitial observations. PLoS One. 2020;15(4):e0231884.

169. Cohen JD, Li L, Wang Y, Thoburn C, Afsari B, Danilova L, et al. Detection and localization of surgically resectable cancers with a multi-analyte blood test. Science. 2018;359(6378):926-30.

170. Chan KC, Jiang P, Sun K, Cheng YK, Tong YK, Cheng SH, et al. Second generation noninvasive fetal genome analysis reveals de novo mutations, single-base parental inheritance, and preferred DNA ends. Proc Natl Acad Sci USA. 2016;113(50):E8159-68.

171. Cirigliano V, Ordonez E, Rueda L, Syngelaki A, Nicolaides $\mathrm{KH}$. Performance of the neoBona test: a new paired-end massively parallel shotgun sequencing approach for cell-free DNA-based aneuploidy screening. Ultrasound Obstet Gynecol. 2017;49(4):460-4.

172. Heitzer E, Auer M, Hoffmann EM, Pichler M, Gasch C, Ulz $\mathrm{P}$, et al. Establishment of tumor-specific copy number alterations from plasma DNA of patients with cancer. Int J Cancer. 2013;133(2):346-56.

173. Liu X, Lang J, Li S, Wang Y, Peng L, Wang W, et al. Fragment enrichment of circulating tumor DNA with low-frequency mutations. Front Genet. 2020;11:147.

174. Esposito Abate R, Frezzetti D, Maiello MR, Gallo M, Camerlingo R, De Luca A, et al. Next generation sequencing-based profiling of cell free DNA in patients with advanced non-small cell lung cancer: advantages and pitfalls. Cancers (Basel). 2020;12(12):3804.

175. Burnham P, Kim MS, Agbor-Enoh S, Luikart H, Valantine HA, Khush KK, et al. Single-stranded DNA library preparation uncovers the origin and diversity of ultrashort cell-free DNA in plasma. Sci Rep. 2016;14(6):27859.

176. Sanchez C, Snyder MW, Tanos R, Shendure J, Thierry AR. New insights into structural features and optimal detection of circulating tumor DNA determined by single-strand DNA analysis. NPJ Genom Med. 2018;3:31.

177. Liu X, Liu L, Ji Y, Li C, Wei T, Yang X, et al. Enrichment of short mutant cell-free DNA fragments enhanced detection of pancreatic cancer. EBioMedicine. 2019;41:345-56. 
178. Moser T, Ulz P, Zhou Q, Perakis S, Geigl JB, Speicher MR, et al. Single-stranded DNA library preparation does not preferentially enrich circulating tumor DNA. Clin Chem. 2017;63(10):1656-9.

179. Lam WKJ, Jiang $\mathrm{P}$, Chan KCA, Cheng SH, Zhang H, Peng W, et al. Sequencing-based counting and size profiling of plasma Epstein-Barr virus DNA enhance population screening of nasopharyngeal carcinoma. Proc Natl Acad Sci USA. 2018;115(22):E5115-24.

180. Mazurek AM, Rutkowski T, Fiszer-Kierzkowska A, Malusecka E, Skladowski K. Assessment of the total cfDNA and HPV16/18 detection in plasma samples of head and neck squamous cell carcinoma patients. Oral Oncol. 2016;54:36-41. 